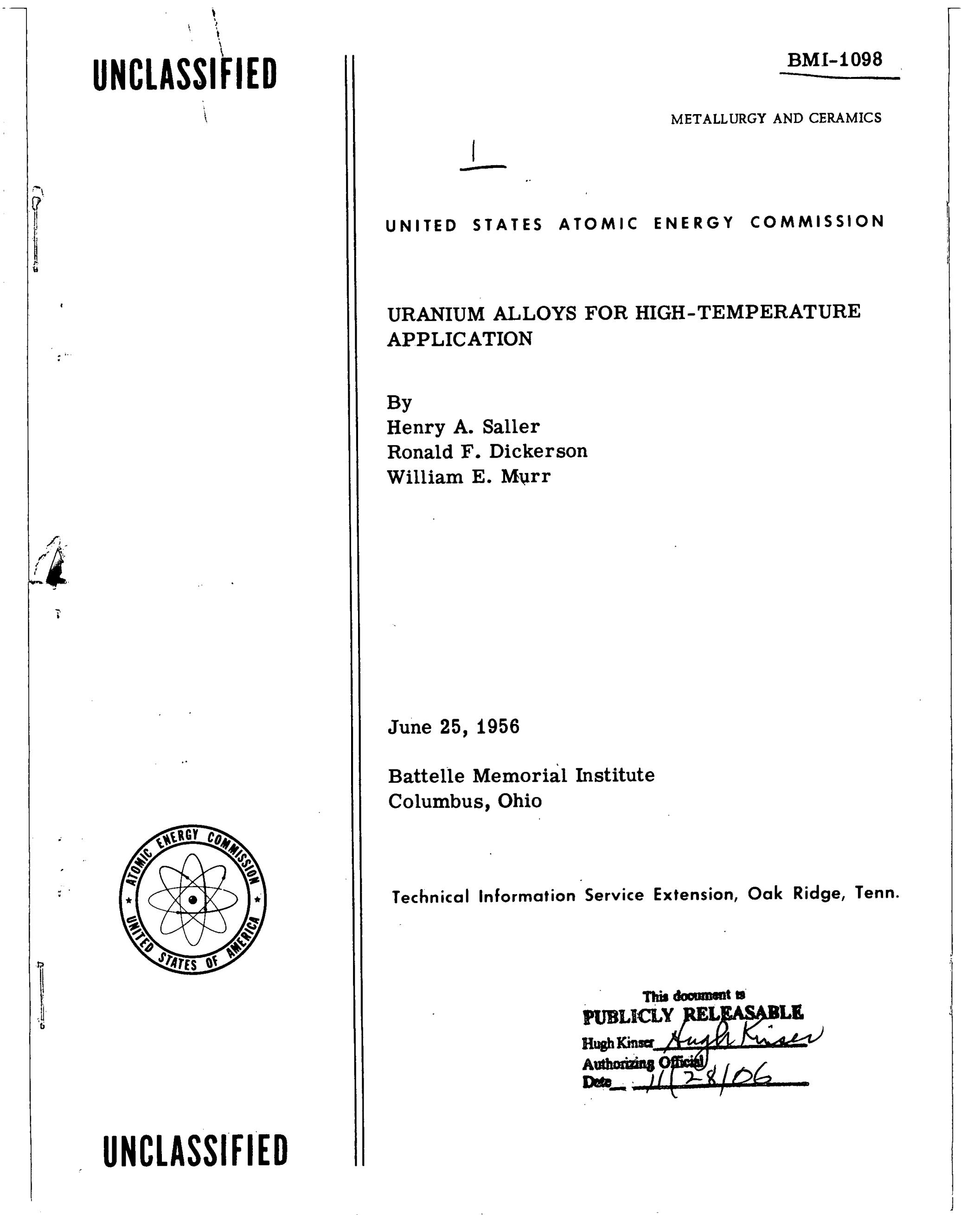




\section{DISCLAIMER}

This report was prepared as an account of work sponsored by an agency of the United States Government. Neither the United States Government nor any agency Thereof, nor any of their employees, makes any warranty, express or implied, or assumes any legal liability or responsibility for the accuracy, completeness, or usefulness of any information, apparatus, product, or process disclosed, or represents that its use would not infringe privately owned rights. Reference herein to any specific commercial product, process, or service by trade name, trademark, manufacturer, or otherwise does not necessarily constitute or imply its endorsement, recommendation, or favoring by the United States Government or any agency thereof. The views and opinions of authors expressed herein do not necessarily state or reflect those of the United States Government or any agency thereof. 


\section{DISCLAIMER}

Portions of this document may be illegible in electronic image products. Images are produced from the best available original document. 
Date Declassified: August 3, 1956.

\section{LEG A L NOTICE}

This report was prepared as an account of Government sponsored work. Neither the United States, nor the Commission, nor any person acting on behalf of the Commission:

A. Makes any warranty or representation, express or implied, with respect to the accuracy, completeness, or usefulness of the information contained in this report, or that the use of any information, apparatus, method, or process disclosed in this report may not inf ringe privately owned rights; or

B. Assumes any liabilities with respect to the use of, or for damages resulting from the use of any information, apparatus, method, or process disclosed in this report.

As used in the above, "person acting on behalf of the Commission" includes any employee or contractor of the Commission to the extent that such employee or contractor prepares, handles or distributes, or provides access to, any information pursuant to his employment or contract with the Commission.

This report has been reproduced directly from the best available copy.

Issuance of this document does not constitute authority for declassification of classified material of the same or similar content and title by the same authors.

Printed in USA. Price 30 cents. Available from the Office of Technical Services, Department of Commerce, Washington 25, D. C. 
BMI-1098

Contract No. W-7405-eng -92

URANIUM ALLOYS FOR HIGH-TEMPERATURE APPLICATION

by

Henry A. Saller

Ronald F. Dickerson

William E. Murr

June 25, 1956

BATTELLE MEMORIAL INSTITUTE

505 King Avenue

Columbus 1, Ohio 
TABLE OF CONTENTS

$\underline{\text { Page }}$

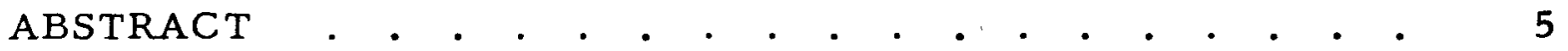

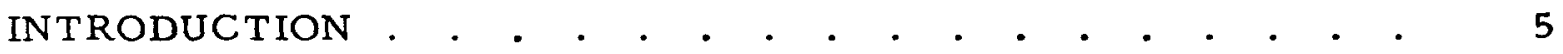

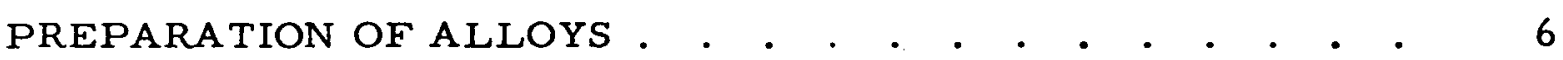

HEAT TREATMENT . . . . . . . . . . . . . . . . 6

Uranium-Zirconium Alloys • . • . . . • . . . . 6

Uranium-Molybdenum Alloys . . . . . . . . . . 16

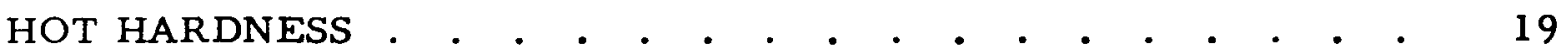

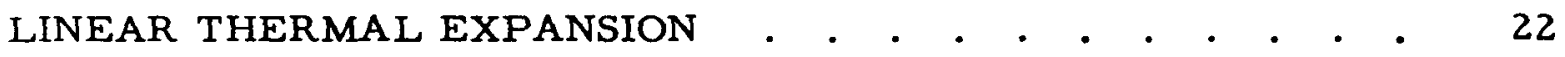

THERMAL CYCLING

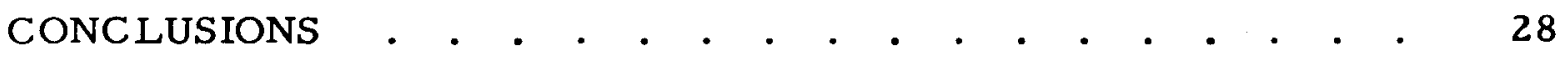

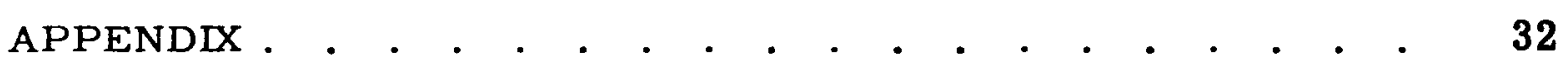




\title{
URANIUM ALLOYS FOR HIGH-TEMPERATURE APPLICATION
}

\author{
Henry A. Saller, Ronald F. Dickerson, \\ and William E. Murr
}

\begin{abstract}
Uranium-molybdenum and uranium-zirconium alloys are of interest as power-reactor fuels. This report deals with some physical properties of uranium-3.5, 5, 7, 9, and 12 \%o molybdenum and uranium-3, 5, 7, 10, 15, and 20-who zirconium alloys. Results of a heat-treatment study, hot-hardness and dilation data, and the effects of beta and gamma thermal cycling upon cylinders of both alloy groups are given.
\end{abstract}

In general, the addition of either zirconium or molybdenum to uranium improved elevated-temperature properties. Uranium-molybdenum alloys possessed greater strengths at elevated temperatures than uranium-zirconium alloys.

Dilation information was obtained upon both uranium-molybdenum and uranium-zirconium alloys in two conditions of heat treatment. A slight decrease in length of uranium-zirconium specimens occurred during dilation studies when cooled from $950 \mathrm{C}$. Conversely, an increase in length occurred with uranium-molybdenum specimens where a transformation was detected.

Thermal cycling revealed that uranium-molybdenum alloys had a greater degree of thermal stability when cycled above $680 \mathrm{C}$ than did the uranium-zirconium alloys. Uranium-zirconium alloys were thermally stable only if cycled below the transformation temperature.

\section{INT RODUCTION}

The proposed use of uranium-zirconium and uranium-molybdenum alloys as power-reactor fuels requires that information be obtained concerning the mechanical and metallurgical properties of the alloys. An investigation was undertaken to provide information on uranium-3.5, 5, 7, 9, and $12 \mathrm{w} / \mathrm{o}$ molybdenum and $3,5,7,10,15$, and $20 \mathrm{w} / \mathrm{o}$ zirconium alloys.

This report is the first of two to be written on the properties of uranium-molybdenum and uranium-zirconium alloys, and gives results of the studies to date. Included are a heat-treatment study, hot-hardness and linear-thermal-expansion data, and behavior of specimens of the alloys in thermal cycling. 
The second report will consist of mechanical-property studies of the same groups of alloys at elevated temperatures, and will be issued at a later date.

\section{PREPARATION OF ALLOYS}

All alloys were prepared by combined induction and consumableelectrode arc-melting processes. The alloys were first induction melted in vacuum and poured from $\mathrm{ZrO}_{2}$ crucibles at a temperature of $1590 \mathrm{C}$ into cold graphite molds. This produced ingots $1-1 / 2$ in. in diameter and approximately $8 \mathrm{in}$. long. The ingots were then melted by the consumableelectrode arc-melting process. All melts were produced from center-cut biscuit and high-purity molybdenum or crystal-bar zirconium. After melting, the 2-1/2-in. consumable ingots were turned to a smooth surface for forging. Chips obtained from turning the ingots were analyzed for zirconium or molybdenum content. Table 1 lists chemical analyses for both groups of alloys.

After melting, the ingots were reduced by forging, rolling, and swaging to rod approximately $7 / 8 \mathrm{in}$. in diameter. The rod was sectioned and additional rolling was carried out on a portion of each alloy to produce 1/2-in.-diameter material for heat-treatment studies. Table 2 lists forging and rolling data for both the uranium-molybdenum and uranium-zirconium alloys.

All of the alloys were fabricated without difficulty.

Following the rolling, the molybdenum alloys were cold swaged to approximately 40 per cent reduction in area. They were then annealed in a salt bath for $1 \mathrm{hr}$ at $1100 \mathrm{~F}$ to prevent cracking.

The zirconium alloys were annealed for $1 \mathrm{hr}$ in vacuum. Following the anneal they were reduced 30 to 35 per cent by cold rolling and then reannealed to prevent cracking.

HEAT TREATMENT

Uranium-Zirconium Alloys

The objectives of heat treating uranium-zirconium alloys were threefold: 

TABLE 1. CHEMICAL ANALYSIS OF URANIUM-ZIRCONIUM
AND URANIUM-MOLYBDENUM ALLOYS

\begin{tabular}{lc}
\hline \hline \multicolumn{1}{c}{ Composition } & (Balance Uranium) $w / 0$ \\
\hline 3.5 molybdenum & Chemical Analysis \\
5.0 molybdenum & 3.34 molybdenum \\
7.0 molybdenum & 4.99 molybdenum \\
9.0 molybdenum & 7.18 molybdenum \\
12.0 molybdenum & 9.36 molybdenum \\
3.0 zirconium & 12.10 molybdenum \\
5.0 zirconium & 2.95 zirconium \\
7.0 zirconium & 4.96 zirconium \\
10.0 zirconium & 7.07 zirconium \\
15.0 zirconium & 9.86 zirconium \\
20.0 zirconium & 15.5 zirconium \\
\hline
\end{tabular}


TABLE 2. FABRICATION HISTORY OF ALLOYS

\begin{tabular}{lcc}
\hline $\begin{array}{c}\text { Nominal Composition } \\
\text { (Balance Uranium), } \\
\text { w/o }\end{array}$ & $\begin{array}{c}\text { Forging } \\
\text { Temperature } \\
\text { F }\end{array}$ & $\begin{array}{c}\text { Rolling } \\
\text { Temperature, } \\
\text { F }\end{array}$ \\
$\begin{array}{l}\text { 3.5 molybdenum } \\
5.0 \text { molybdenum }\end{array}$ & 1125 & 1125 \\
7.0 molybdenum & 1500 & 1500 \\
9.0 molybdenum & 1600 & 1600 \\
12.0 molybdenum & 1800 & 1650 \\
3.0 zirconium & 1800 & 1800 \\
$5,7,10,15$ zirconium & 1125 & 1125 \\
20 zirconium & 1500 & 1500 \\
\hline \hline
\end{tabular}


(1) To produce a fine grain size in the alloys

(2) To produce a variation in size and distribution of the alpha-uranium and epsilon phases

(3) To produce a homogeneous structure as a means of eliminating or reducing preferential growth during irradiation.

The heat-treatment response of the uranium-zirconium alloys was determined on specimens approximately $1 / 2 \mathrm{in.}$ in diameter and $1 / 4 \mathrm{in}$. thick. All specimens were heated in vacuum for $1 \mathrm{hr}$ at $800 \mathrm{C}$ before cooling. The structures obtained were a result of the cooling rates utilized. The heat treatments are listed below, along with a brief description of the objective for each specific treatment:

A. Heat Treatment A consisted of heating specimens for $1 \mathrm{hr}$ at $800 \mathrm{C}$ and furnace cooling them. This is a standard treatment for uranium-zirconium alloys. Representative microstructures for this treatment are those of uranium-5 and $15 \mathrm{w} / \mathrm{o}$ zirconium alloys (Figure 1). The grain size showed a gradual decrease with zirconium content and a gradual change from the acicular structure of uranium-5 w/o zirconium to the lamellar structure of the uranium-15 w/o zirconium alloys.

B. Heat Treatment B consisted of heating specimens for $1 \mathrm{hr}$ at $800 \mathrm{C}$ and furnace cooling them at the rate of $1 / 2 \mathrm{C}$ per min between 750 and $570 \mathrm{C}$. This treatment was intended to provide equilibrium precipitates of gamma and epsilon uranium, and to coarsen the structure. Representative microstructures of this treatment are shown in Figure 2 for uranium $-5 \mathrm{w} / \mathrm{o}$ and $15 \mathrm{w} / \mathrm{o}$ zirconium. The same trends appearing for Heat $T$ reatment $A$ appear in this group of photographs. However, the larger grain sizes and coarser structures are the apparent result of the slower controlled furnace cool.

C. Heat Treatment $C$ consisted of heating specimens for $1 \mathrm{hr}$ at $800 \mathrm{C}$, then isothermally transforming them for $2 \mathrm{hr}$ at $550 \mathrm{C}$ and water quenching. This treatment was designed to provide numerous nucleation sites in the material. It was given to specimens as a single treatment and in combination with Heat $T$ reatment $D$ (Heat Treatments $C D$ and CDD). 

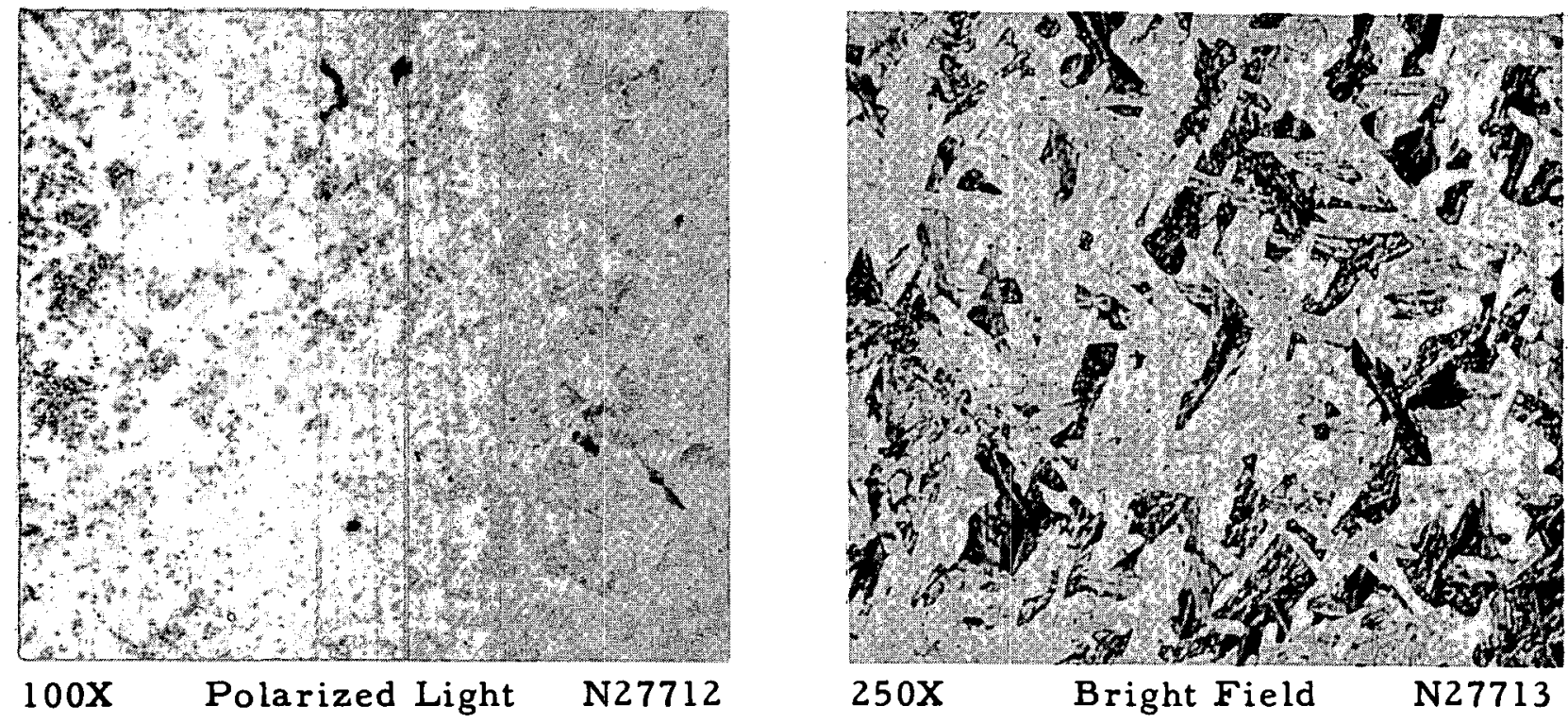

Uranium-5 w/o Zirconium
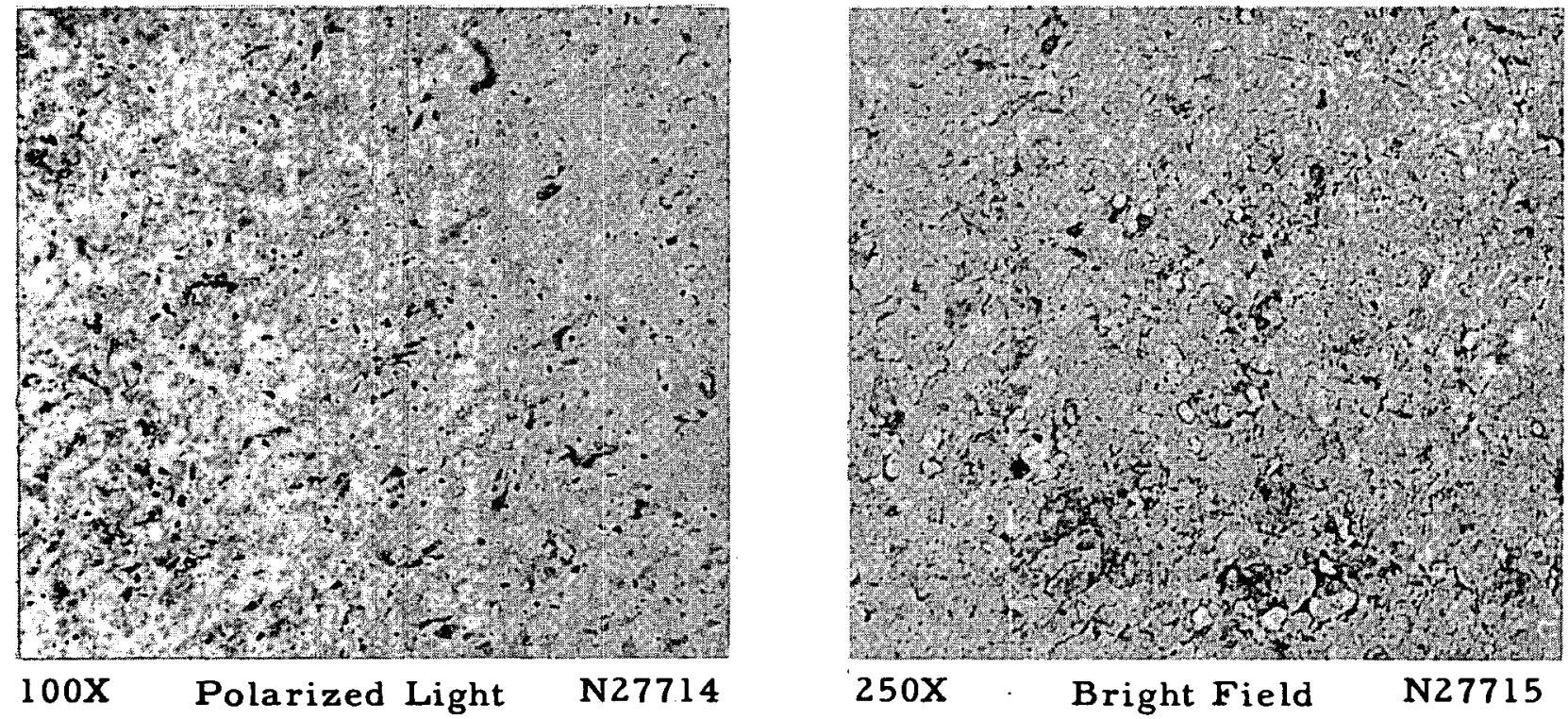

Uranium-15 w/o Zirconium

FIGURE 1. ALLOYS HEATED 1 HR AT $800 \mathrm{C}$ AND FURNACE COOLED (HEAT TREATMENT A) 


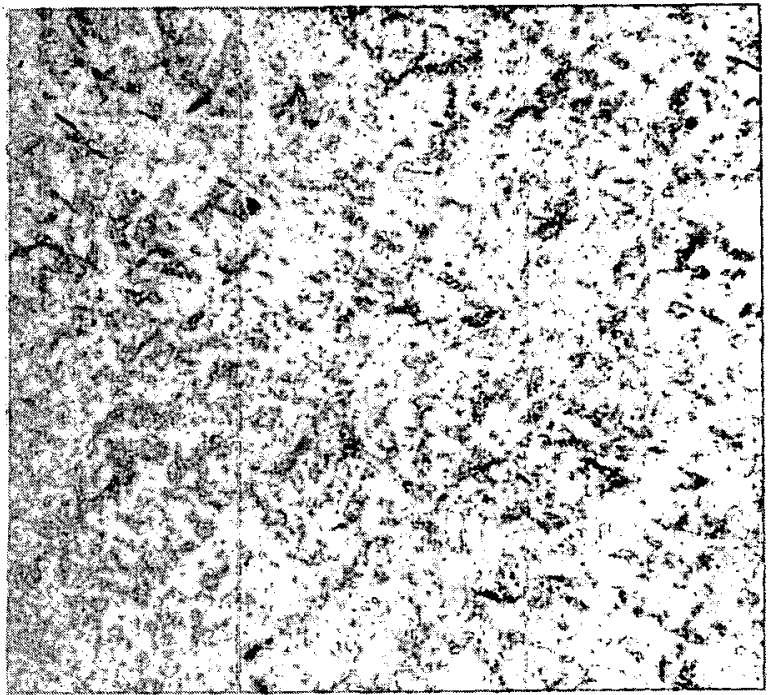

100X Polarized Light N27716

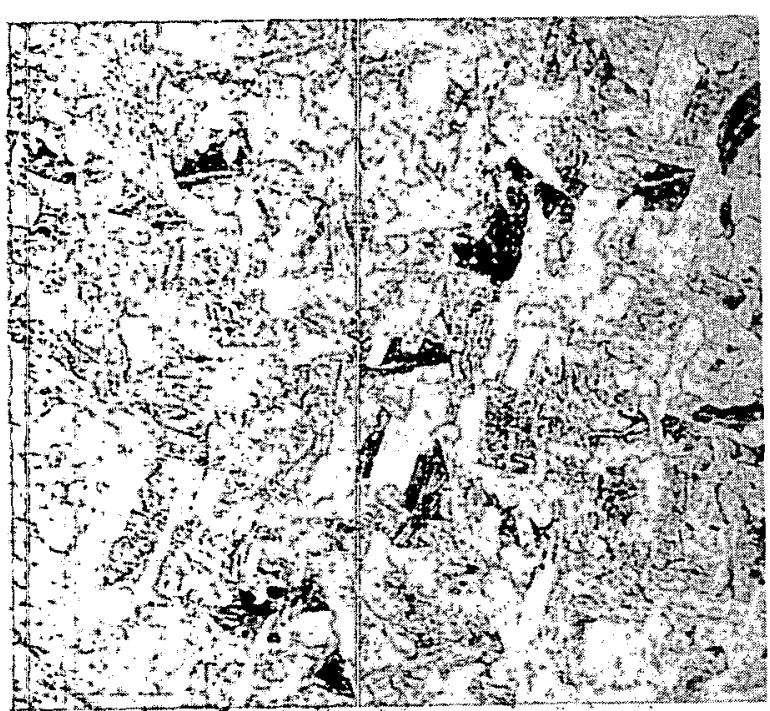

250X Bright Field

N27717

Uranium-5 w/o Zirconium
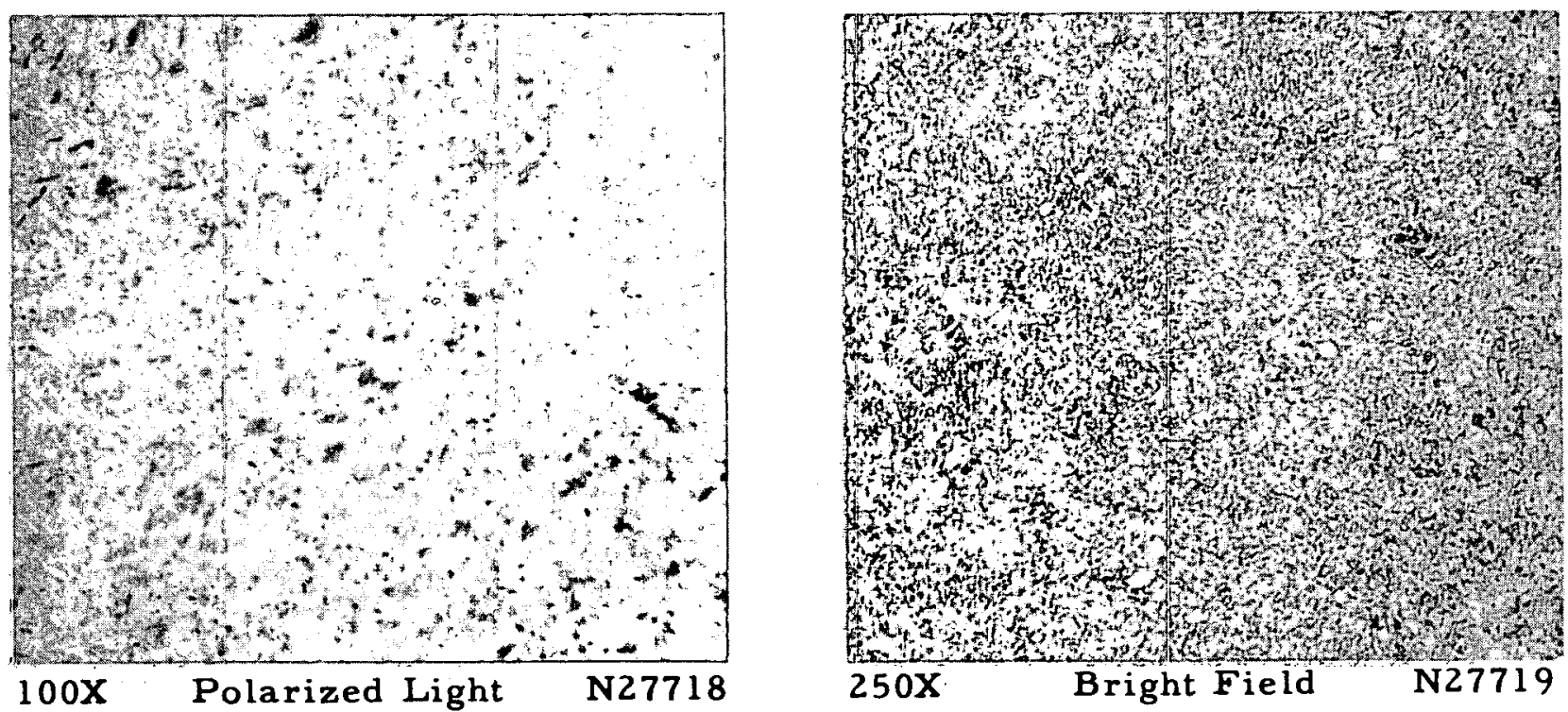

Uranium-15.w/o Zirconium

FIGURE 2. SPECIMENS HEAT TREATED 1 HR AT $800 \mathrm{C}$, FURNACE COOLED TO $750 \mathrm{C}$, AND COOLED FROM $750 \mathrm{C}$ TO 570 C AT A RATE OF 1/2 C PER MIN ( HEAT TREATMENT B) 
D. Heat Treatment $D$ consisted of heating specimens for $1 \mathrm{hr}$ at $800 \mathrm{C}, 5 \mathrm{~min}$ at $780 \mathrm{C}$, and isothermally transforming them for $2 \mathrm{hr}$ at $550 \mathrm{C}$. The treatment was designed to increase randomization of structure. Examination revealed that Heat Treatments $C, C D$, and CDD produced essentially the same results. Heat Treatment $D$ was repeated on specimens with the aim of increasing randomization. A sharp break in grain size resulting from the treatment occurred between specimens of uranium $-7 \mathrm{w} / 0$ and $10 \mathrm{w} / 0$ zirconium. Typical structures produced by these treatments are those of uranium-5 and $10 \mathrm{w} / \mathrm{o}$ zirconium (Figure 3 ).

E. Heat Treatment $E$ consisted of heating specimens for $1 \mathrm{hr}$ at $800 \mathrm{C}$, furnace cooling to $670 \mathrm{C}$, annealing at that temperature for $24 \mathrm{hr}$, and then furnace cooling to room temperature. Typical structures produced by this treatment are those of uranium-5 and $15 \mathrm{w} / \mathrm{o}$ zirconium alloys (Figure 4). The prolonged annealing time at $670 \mathrm{C}$ has evidently succeeded in coarsening the phase particles present. Grain size again shows a gradual decreasing tendency with increased zirconium content.

F. Heat Treatment $F$ consisted of water quenching specimens after $1 \mathrm{hr}$ at $800 \mathrm{C}$, reheating them to $670 \mathrm{C}$ for $24 \mathrm{hr}$ and then furnace cooling them. This treatment was designed to show structural variation obtained by holding gammaquenched specimens at alpha plus gamma temperatures. It produced in alloys containing up to $10 \mathrm{w} / \mathrm{o}$ zirconium a martensitic structure that retained its features after being annealed at $670 \mathrm{C}$. Typical structures of Heat Treatment F are those of the 5 and $20 \mathrm{w} / 0$ zirconium alloys represented by photomicrographs in Figure 5.

In general, when uranium-zirconium alloys are cooled at slow rates there is a gradual change both in grain size and phase distribution with increasing zirconium content. Both grain size and particle size show a tendency toward refinement. However, upon rapid cooling from the gamma phase, there is apparently a fairly sharp division between 7 to $10 \mathrm{w} / 0 \mathrm{zir}-$ conium with respect to grain sizes developed. The phase distribution also changes, but at a more gradual rate. 


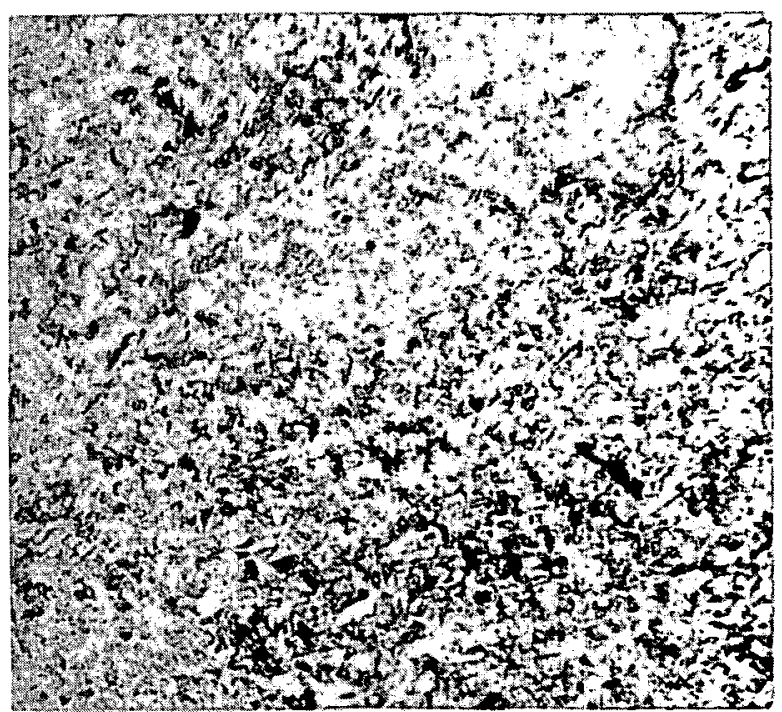

100X Polarized Light N27720

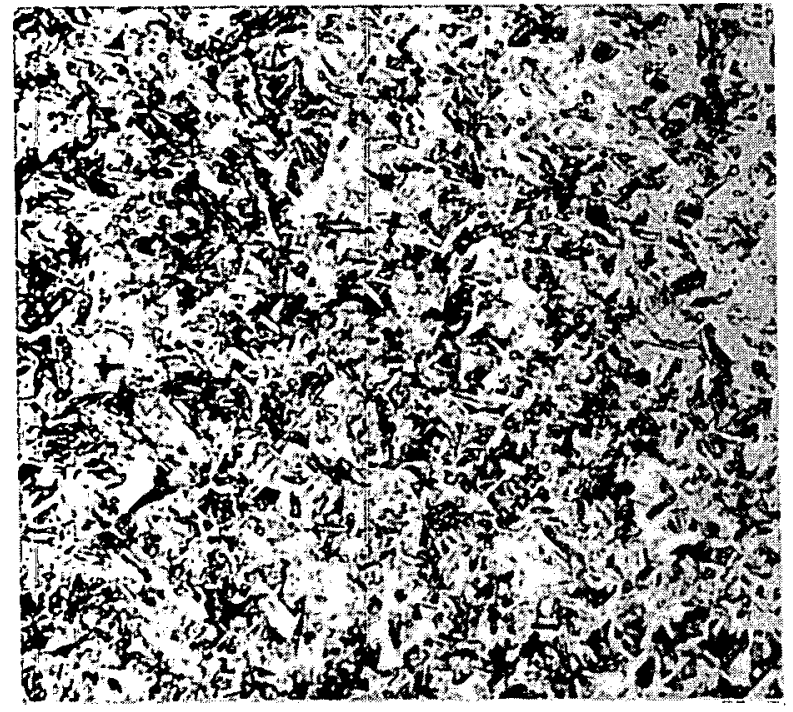

250X Bright Field

N27721

Uranium-5 w/o Zirconium
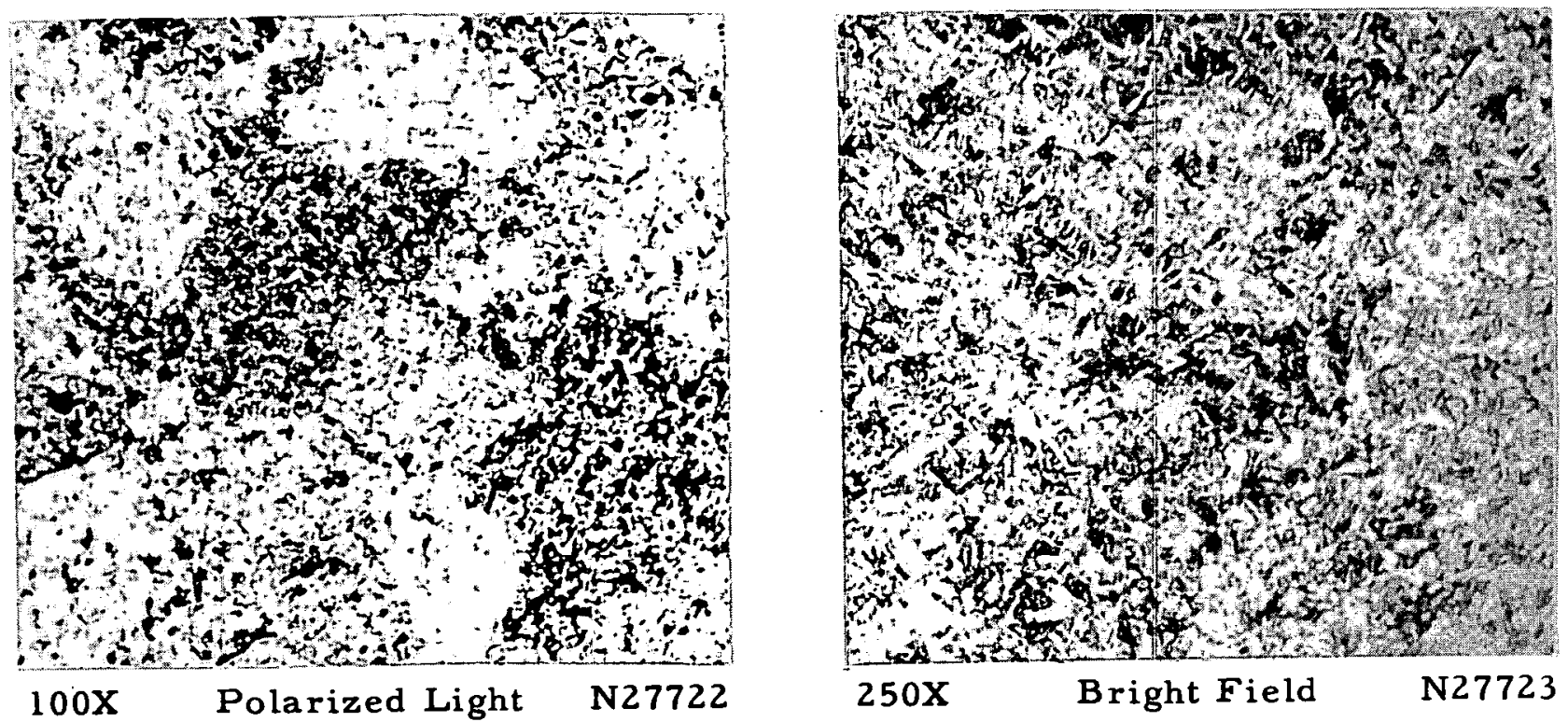

Uranium-10 w/o Zirconium

FIGURE 3. ALLOYS HEAT TREATED I HR AT $800 \mathrm{C}, 2 \mathrm{HR}$ AT $550 \mathrm{C}$, 5 MIN AT $780 \mathrm{C}, 2 \mathrm{HR}$ AT $550 \mathrm{C}, 5 \mathrm{MIN}$ AT $780 \mathrm{C}, 2 \mathrm{HR}$ AT $550 \mathrm{C}$, AND FURNACE COOLED (HEAT TREATMENT CDD) 

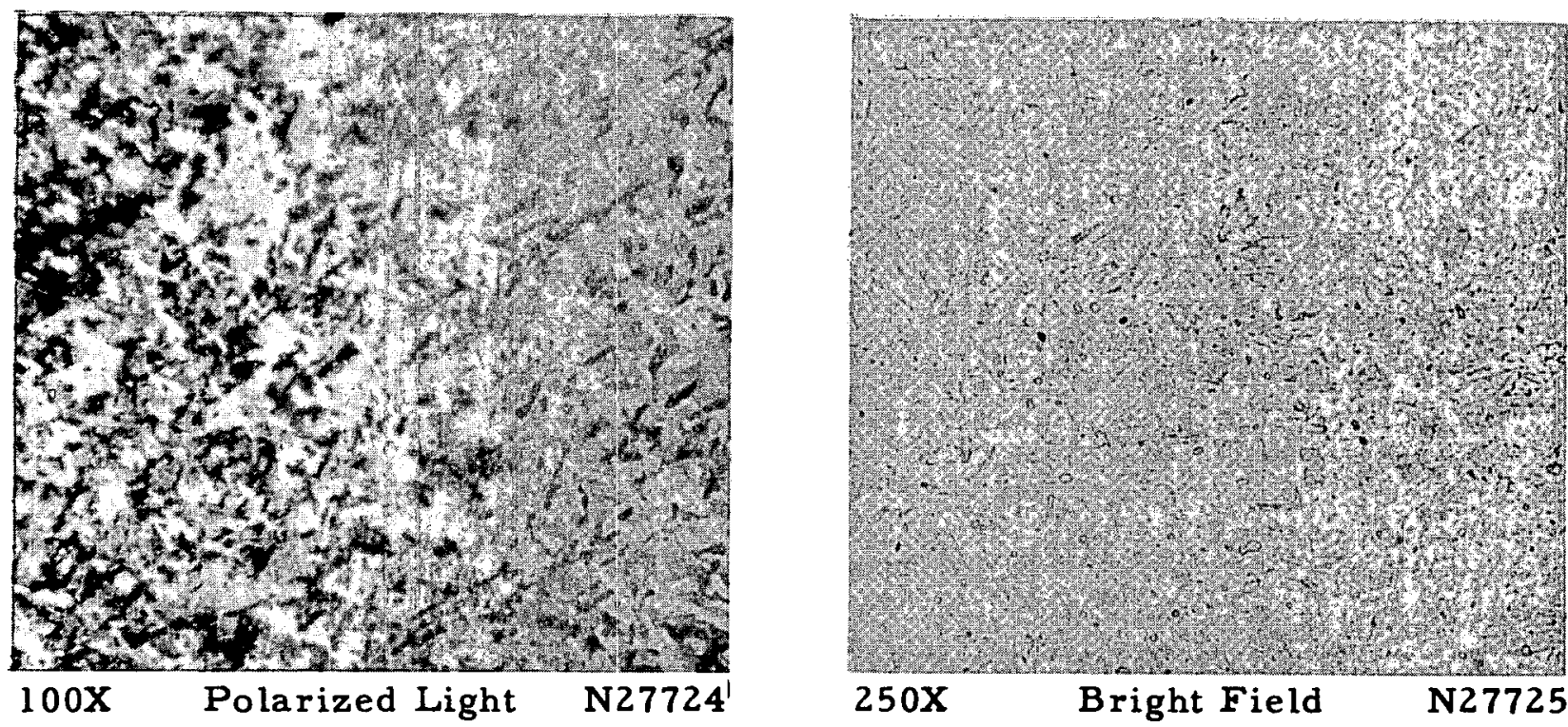

Uranium -5 w/o Zirconium
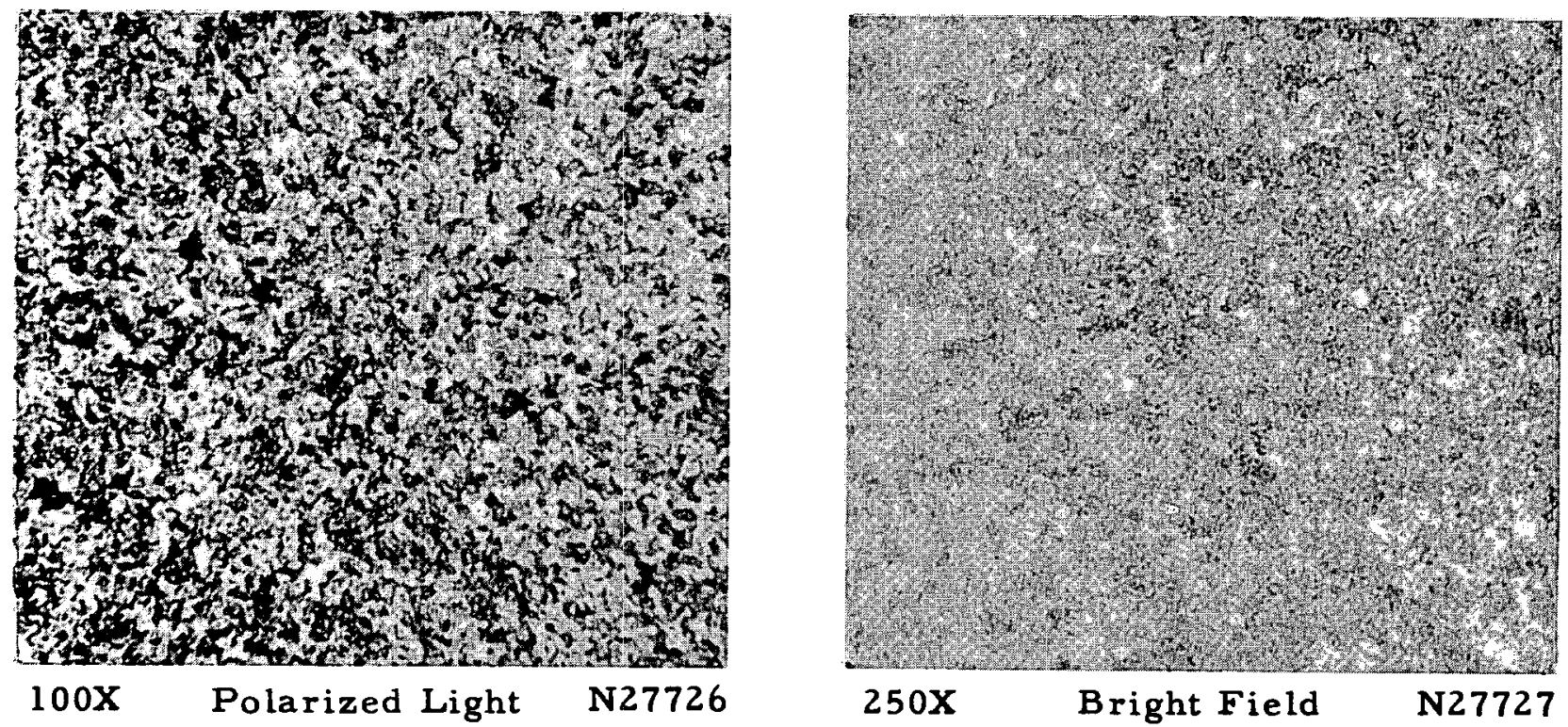

Uranium-15 w/o Zirconium

FIGURE 4. SPECIMENS HEAT TREATED 1 HR AT $800 \mathrm{C}$, FURNACE COOLED TO $670 \mathrm{C}$, HELD $24 \mathrm{HR}$, AND FURNACE COOLED (HEAT TREATMENT E) 

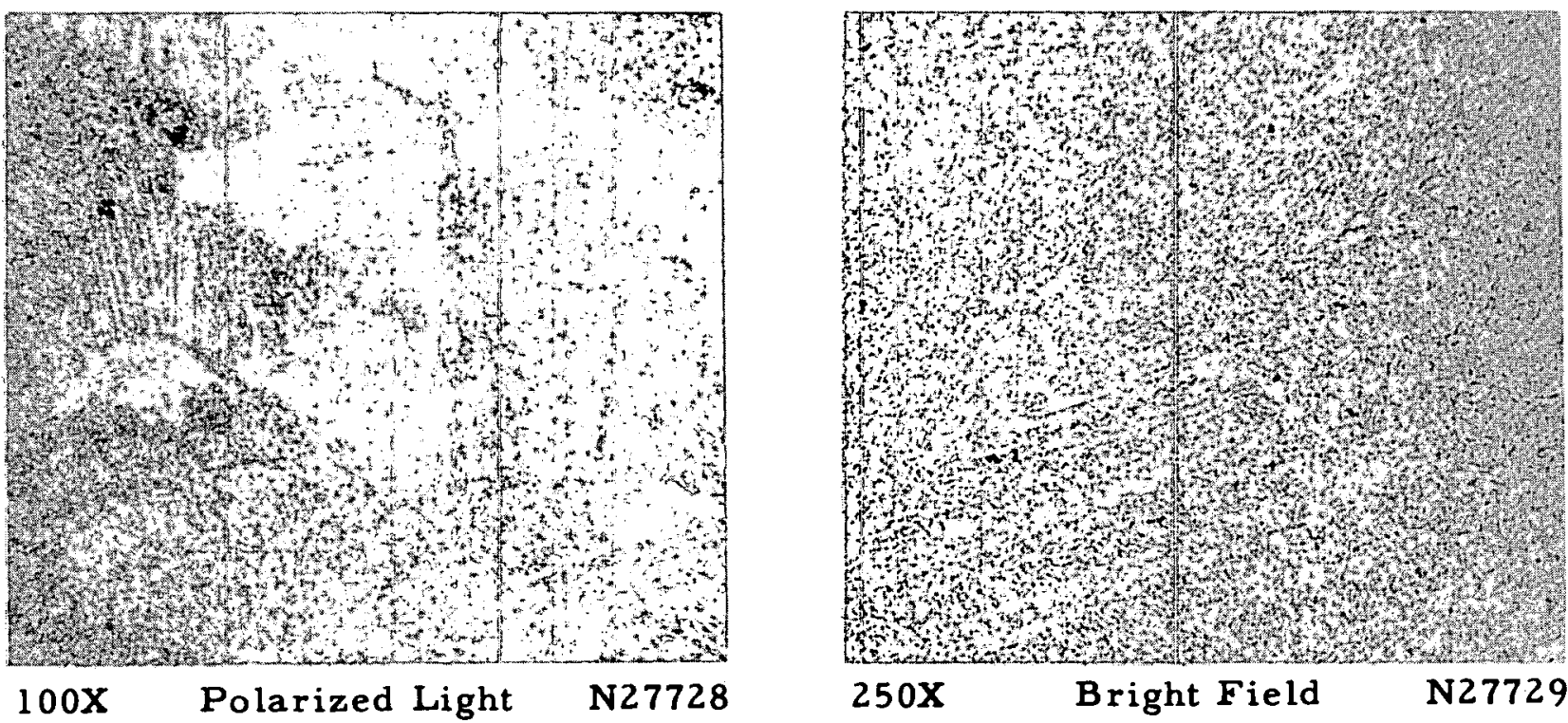

Uranium $-5 \mathrm{w} / 0 \mathrm{Zirconium}$
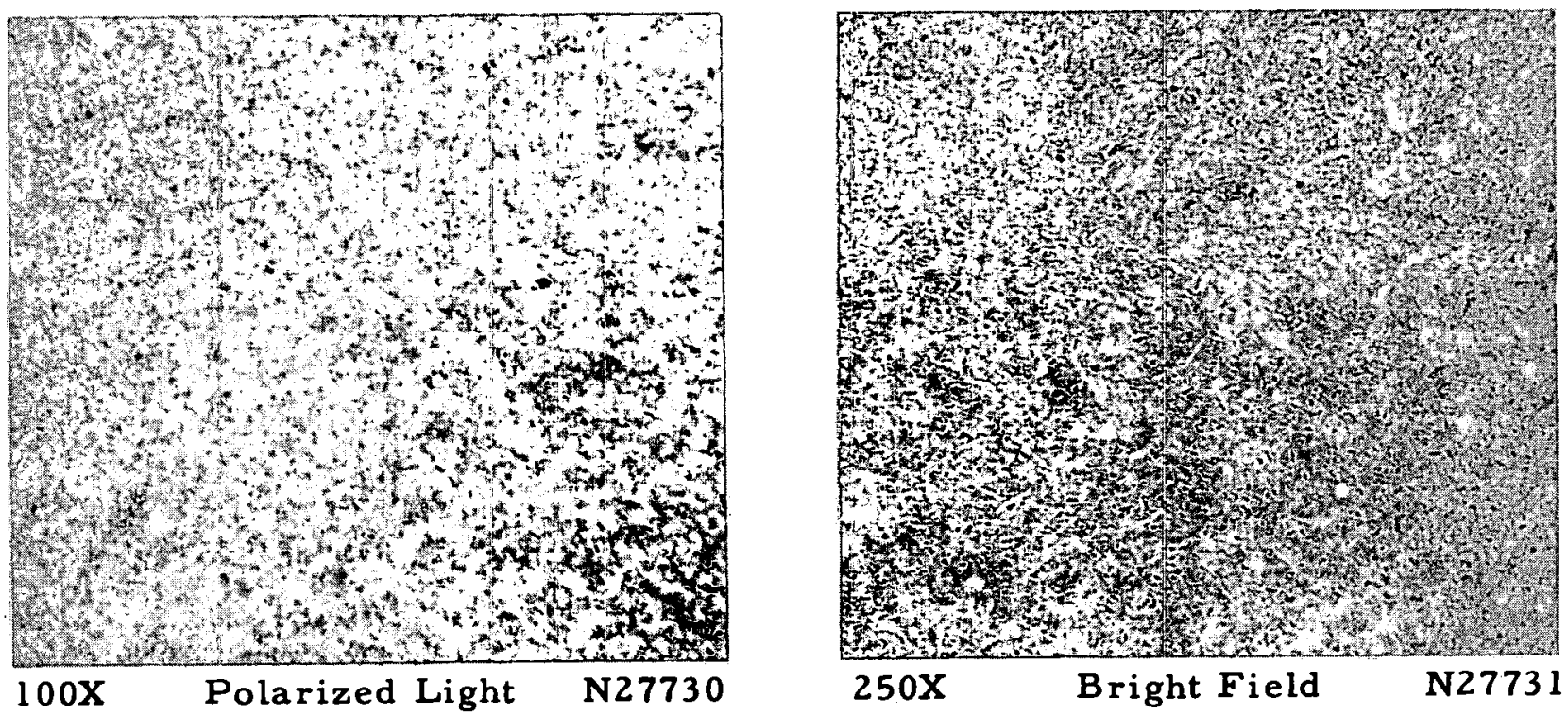

Uranium-20 w/o Zirconium

FIGURE 5. SPECIMENS HEAT TREATED 1 HR AT $800 \mathrm{C}$, WATER QUENCHED; 24 HR AT $670 \mathrm{C}$, AND FURNACE COOLED (HEAT TREATMENT F) 
Uranium-Molybdenum Alloys

Each of the uranium-molybdenum alloys received two heat treatments. The purpose of these treatments was to produce specimens with retainedgamma structures and with nearly-transformed-gamma structures. Retained-gamma structures were produced by water quenching specimens from $800 \mathrm{C}$, and transformed structures were obtained by permitting transformation to take place at $500 \mathrm{C}$. Transformation time was a function of molybdenum content, with higher molybdenum alloys requiring a greater period of time for transformation. The heat treatments are listed below:

G. $1 \mathrm{hr}$ at $800 \mathrm{C}$, water quenched

H. $1 \mathrm{hr}$ at $800 \mathrm{C}$, air cooled (specimen protected in an evacuated glass envelope)

J. $1 \mathrm{hr}$ at $800 \mathrm{C}$, furnace cooled to $500 \mathrm{C}$, held $24 \mathrm{hr}$, furnace cooled

K. l hr at $800 \mathrm{C}$, furnace cooled to $500 \mathrm{C}$, held $100 \mathrm{hr}$, furnace cooled

L. $1 \mathrm{hr}$ at $800 \mathrm{C}$, furnace cooled to $500 \mathrm{C}$, held $200 \mathrm{hr}$, furnace cooled

M. $1 \mathrm{hr}$ at $800 \mathrm{C}$, furnace cooled to $500 \mathrm{C}$, held 2 weeks, furnace cooled.

Figure $6 a$ is of gamma-quenched uranium-5 w/o molybdenum given Heat Treatment G. The photomicrographs reveal the martensitic structure known as alpha prime, which is characteristic of the alloys with lower molybdenum contents. Figure $6 \mathrm{~b}$ is of uranium-5 w/o molybdenum that was partially transformed by soaking at $500 \mathrm{C}$ for $24 \mathrm{hr}$ (Heat Treatment J).

Transformation has resulted in the appearance of a precipitate of the alphauranium and the intermediate-delta phases.

Figures $7 \mathrm{a}$ and $7 \mathrm{~b}$ are of uranium-12 w/o molybdenum alloys gamma quenched and transformed, respectively. The martensitic or alpha-prime structure present in the alloys of lower molybdenum contents is missing in the gamma-quenched specimen. However, in the transformed specimen, a precipitate borders the grain boundaries and is identified as alpha uranium and delta. 


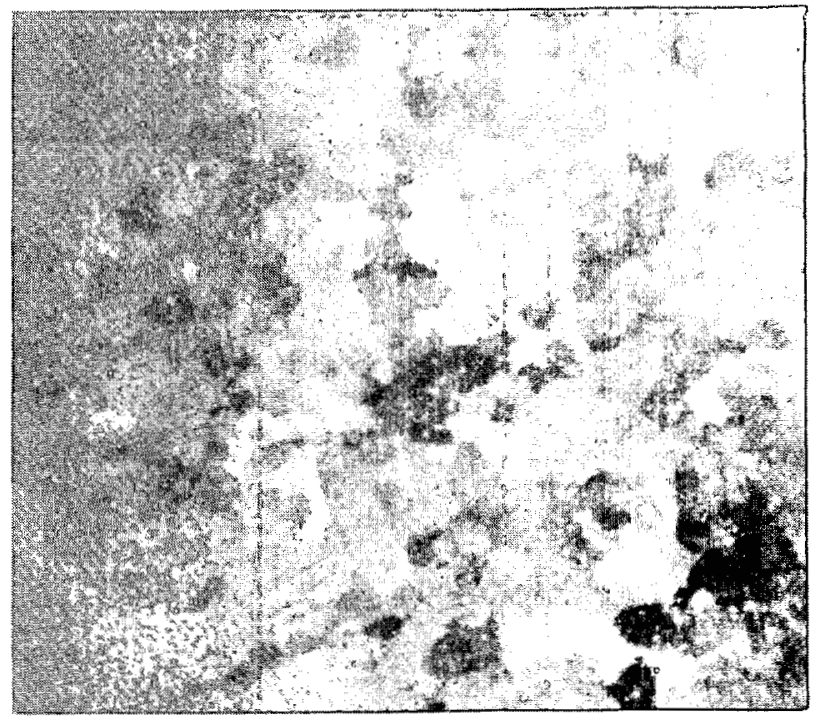

$100 \mathrm{x}$

Polarized Light

N27732

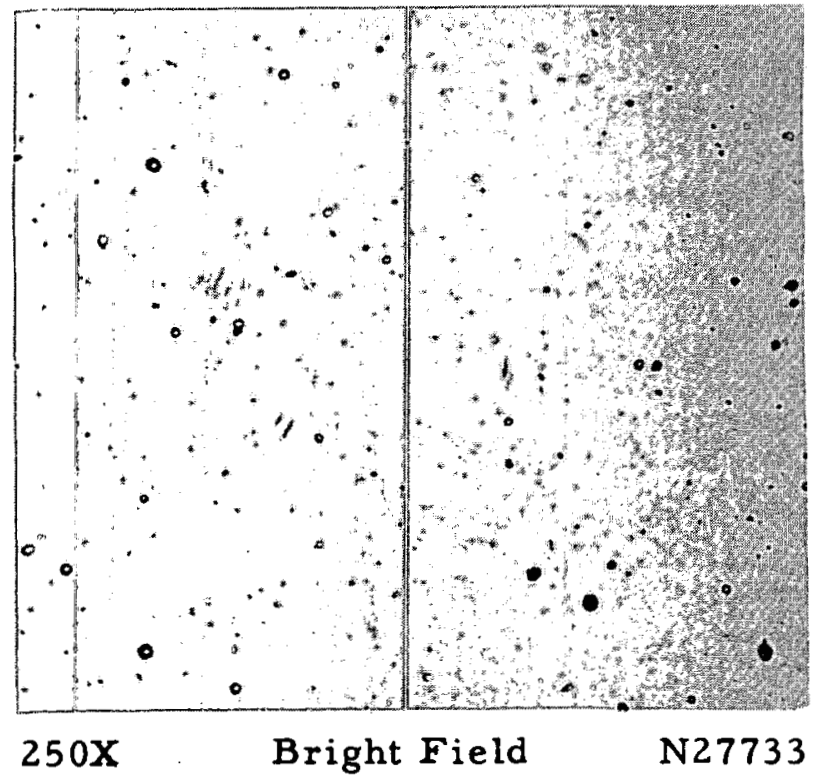

a. Gamma-Quenched Uranium-5 w/o Molybdenum Heat Treated for $1 \mathrm{Hr}$ at $800 \mathrm{C}$ and Water Quenched (Heat Treatment $\mathrm{G}$ )
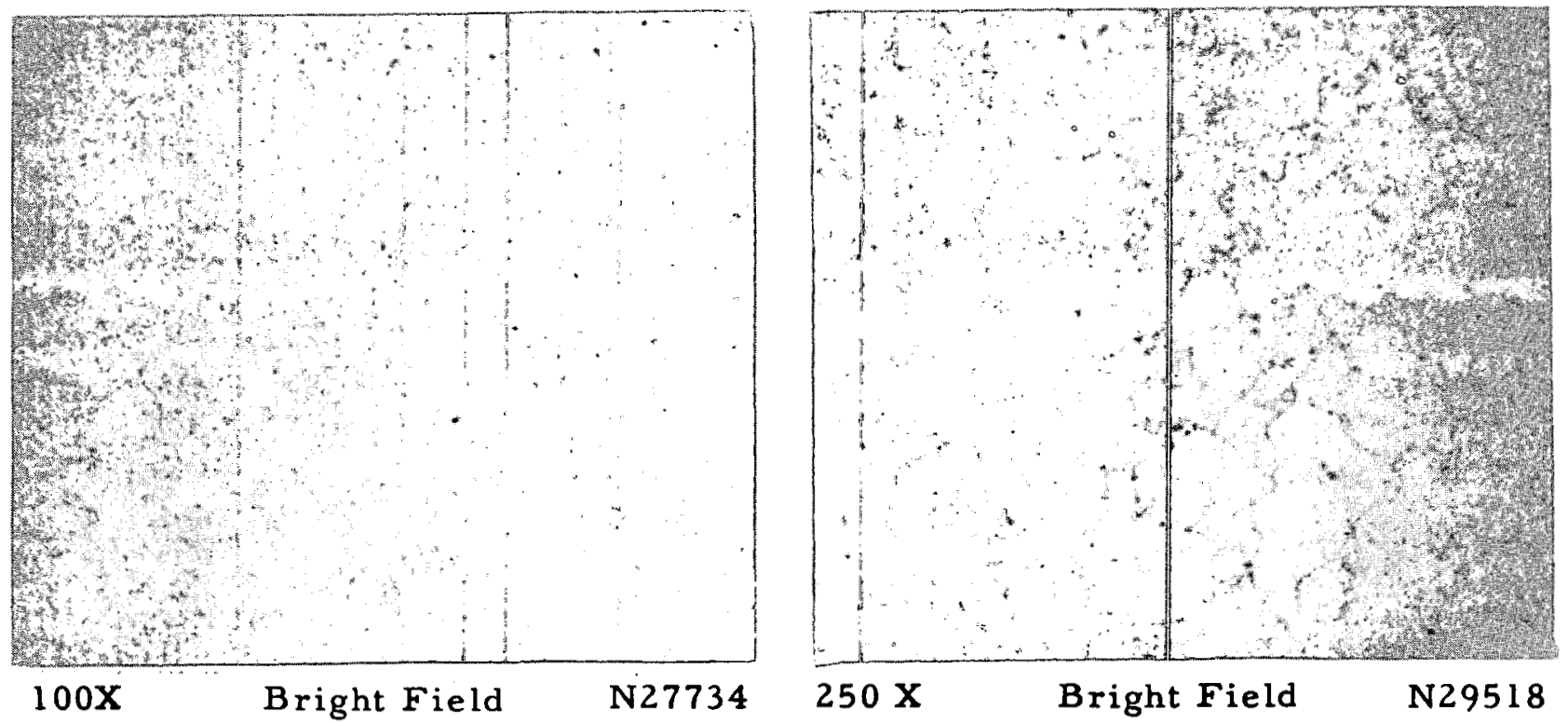

b. Transformed Uranium-5 w/o Molybdenum Heat Treated for $1 \mathrm{Hr}$ at $800 \mathrm{C}$, Furnace Cooled to $500 \mathrm{C}$, Held $24 \mathrm{Hr}$, and Furnace Cooled (Heat Treatment $\mathrm{J}$ )

FIGURE 6. GAMMA-QUENCHED AND TRANSFORMED URANIUM-5 w/o MOLYBDENUM SPECIMENS 

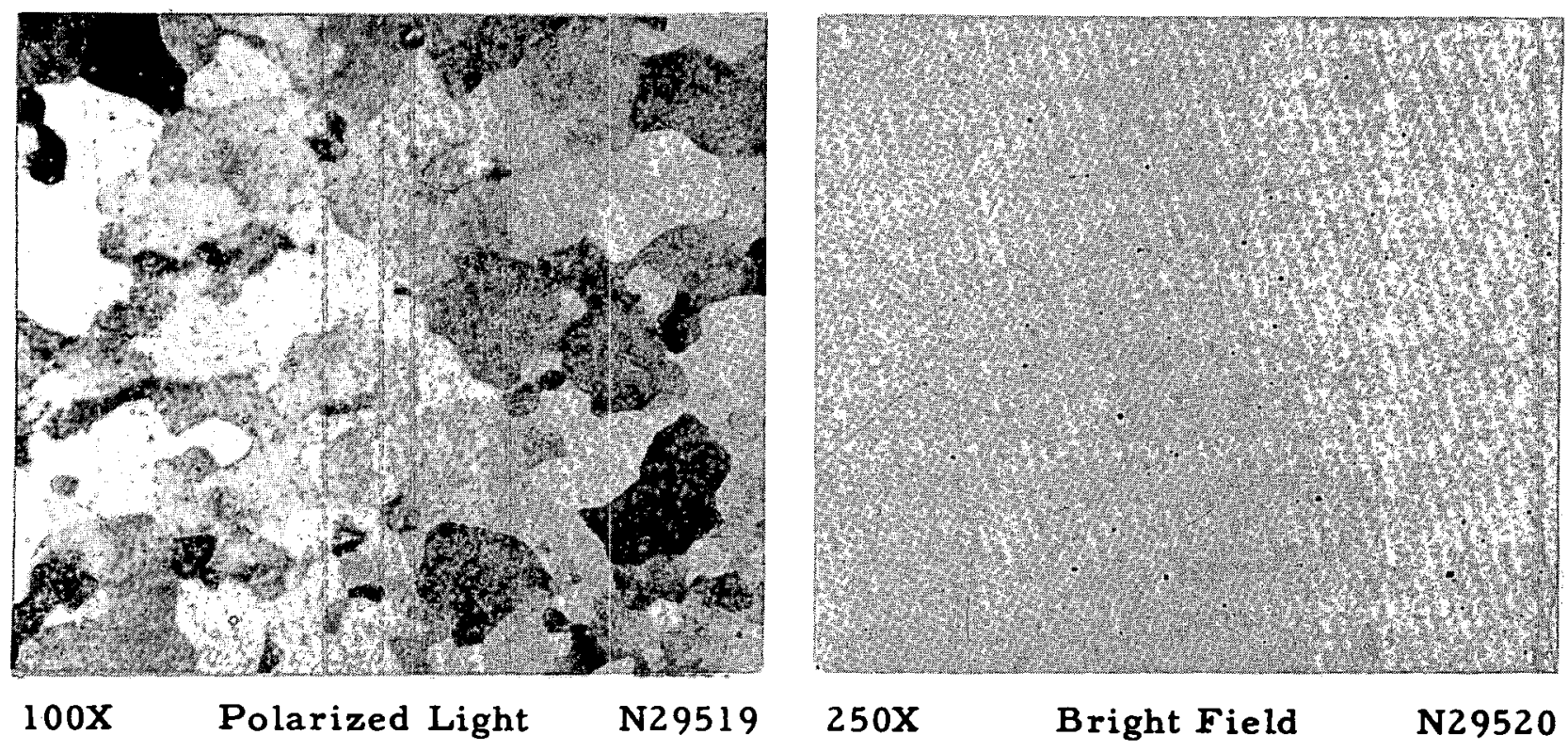

100X Polarized Light N29519 250X $\quad$ Bright Field $\quad$ N29520

a. Gamma-Quenched Uranium-12 w/o Molybdenum Heat Treated for $1 \mathrm{Hr}$ at $800 \mathrm{C}$ and Water Quenched (Heat Treatment G)
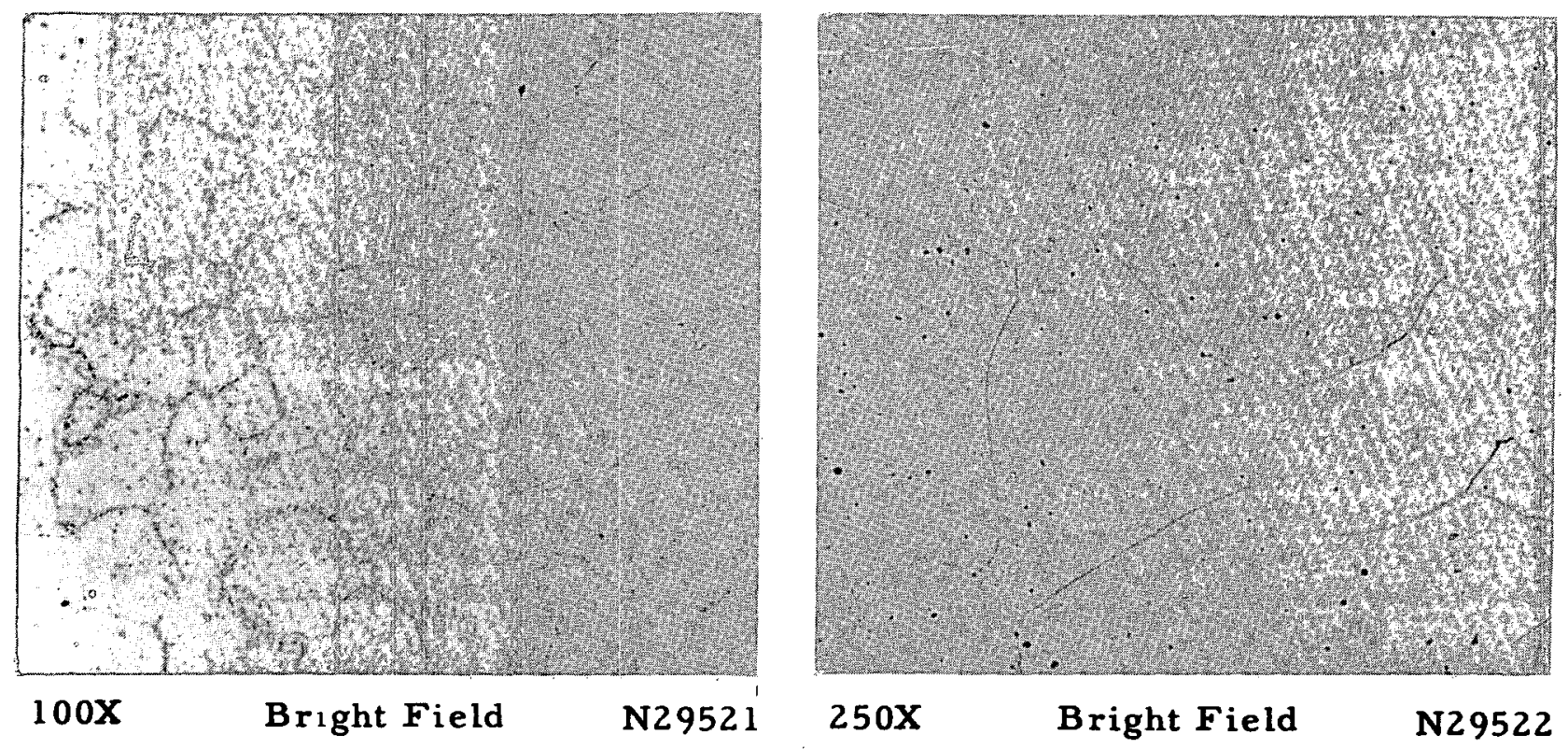

b. Transformed Uranium-12 w/o Molybdenum Heat Treated for $1 \mathrm{Hr}$ at $800 \mathrm{C}$, Furnace Cooled to $500 \mathrm{C}$, Held 2 Weeks, and Furnace Cooled (Heat Treatment $M$ )

FIGURE 7. GAMMA-QUENCHED SPECIMENS AND TRANSFORMED SPECIMENS OF URANIUM-12 w/O MOLYBDENUM 
HOT HARDNESS

The strength of uranium is affected by the amount of alloy materials added. In the case of uranium-zirconium and uranium-molybdenum alloys, an indication of the relative high-temperature strengths of these materials was obtained through measurements of hot hardness. The ease with which values may be obtained over a wide range of temperature makes this method practical for evaluating various compositions and heat treatments.

In this study, hot-hardness values were obtained on uranium- 3 through $20 \mathrm{w} / \mathrm{o}$ zirconium and uranium 3.5 through $12.0 \mathrm{w} / \mathrm{o}$ molybdenum alloys. In the uranium-zirconium series, values were obtained for four different conditions of heat treatment, while in the uranium-molybdenum series hardness values of alloys in two heat-treated conditions were obtained.

Table 3 lists data on hardness of uranium-zirconium alloys at room temperature and at selected temperatures in the range between 600 and $800 \mathrm{C}$. The numbers reported are the average of three to five readings at each temperature. Where no numbers are given, the readings were inconsistent or were not obtained because of insufficient specimen.

From Table 3 it is apparent that some heat treatments have pronounced effects upon hot-hardness values of uranium-zirconium alloys. An example of this is the greatly improved hardness of uranium-3 w/o zirconium between 700 and $750 \mathrm{C}$ when slowly cooled through the gamma transformation (Heat Treatment $E$ on Table 3). The room-temperature hardness of alloys water quenched from $800 \mathrm{C}$ is much greater than hardnesses obtained by any other method of heat treatment investigated.

Further investigation of the table reveals that above $700 \mathrm{C}$, an increase in hardness is accomplished by increasing the zirconium content. This condition continues until approximately $15 \mathrm{w} / \mathrm{o}$ zirconium has been added. Between 15 and $20 \mathrm{w} / \mathrm{o}$ addition of zirconium, the hardness of the resultant alloy is decreased at temperatures above $700 \mathrm{C}$. This suggests that the greatest high-temperature strength of uranium-zirconium in the range studied is in the vicinity of $15 \mathrm{w} / \mathrm{o}$ zirconium.

Table 4 lists room-temperature and hot hardness of uraniummolybdenum alloys between 600 and $800 \mathrm{C}$. The alloys were heat treated to obtain retained- and nearly transformed-gamma structures. Transformed structures were produced in specimens by allowing them to soak for a period of time at $500 \mathrm{C}$. In general, the period of time required for transformation was increased by increasing the molybdenum content of the alloys. 
TABLE 3. HOT-HARDNESS DATA ON URANIUM-ZIRCONIUM ALLOYS

\begin{tabular}{|c|c|c|c|c|c|c|c|c|c|}
\hline \multirow{2}{*}{$\begin{array}{c}\text { Zirconium Content } \\
\text { (Balance Uranium), } \\
\text { w/o }\end{array}$} & \multirow[b]{2}{*}{ Heat Treatment(a) } & \multicolumn{8}{|c|}{ Hardness, DPH, kg per $\mathrm{mm}^{2}$} \\
\hline & & $\begin{array}{c}\text { Room } \\
\text { Temperature }\end{array}$ & $600 \mathrm{C}$ & $650 \mathrm{C}$ & $680 \mathrm{C}$ & $700 \mathrm{C}$ & $725 \mathrm{C}$ & $750 \mathrm{C}$ & $800 \mathrm{C}$ \\
\hline 3.0 & A & 285 & 67 & 36 & 29 & 5.1 & 2.3 & 2.2 & -- \\
\hline 3.0 & $\mathbf{F}$ & 473 & 48.2 & 26.3 & 13.3 & 4.1 & 2.4 & 2.6 & 2.1 \\
\hline 3.0 & E & 266 & 49.0 & 27.6 & 9.3 & 15.7 & 13.1 & 10.9 & -- \\
\hline 3.0 & CDD & 269 & 47.5 & 35.0 & 22.8 & 4.7 & 2.4 & 1.6 & -- \\
\hline 5.0 & $A$ & 336 & 42 & 34 & 10.7 & 6.0 & 5.4 & 4.5 & - \\
\hline 5.0 & $\mathrm{~F}$ & 513 & 44.5 & 26.7 & 7.0 & 6.6 & 5.9 & 4.7 & 3.0 \\
\hline 5.0 & E & 295 & 37.2 & 35.3 & 19.5 & 7.7 & 6.0 & 5.2 & -- \\
\hline 5.0 & CDD & 316 & 49.8 & 36.2 & 22.5 & 4.4 & 2.6 & 2.7 & 2.7 \\
\hline 7.0 & A & 352 & -- & 31.0 & 11.7 & 9.0 & 8.0 & 7.1 & 4.8 \\
\hline 7.0 & $\mathbf{F}$ & 420 & -- & -- & 10.6 & 9.3 & 8.7 & 7.2 & 4.9 \\
\hline 7.0 & $\mathrm{E}$ & 306 & -- & -- & 12.8 & 10.8 & 8.5 & 7.7 & 5.9 \\
\hline 7.0 & CDD & 338 & 45.9 & 37.8 & 13.0 & 5.8 & 6.4 & 5.0 & 3.6 \\
\hline 10.0 & A & 364 & 53.0 & 23.0 & 7.6 & 14.2 & 12.3 & 9.9 & -- \\
\hline 10.0 & $\mathrm{~F}$ & 540 & 49.0 & 26.5 & 13.4 & 13.7 & 11.0 & 8.2 & - \\
\hline 10.0 & $E$ & 312 & 39.7 & 30.7 & 27.3 & 4.3 & 2.5 & 2.3 & 1.8 \\
\hline 10.0 & CDD & 341 & 46.5 & 33.9 & 9.8 & 16.0 & 12.8 & 8.7 & - \\
\hline 15.0 & A & 372 & 71 & 28 & 15.0 & 17.5 & 14.9 & 12.4 & -- \\
\hline 15.0 & $F$ & 462 & 43.8 & 32.3 & 15.8 & 15.5 & 13.9 & 11.3 & 7.0 \\
\hline 15.0 & $E$ & 317 & 63.9 & 30.9 & 15.5 & 19.5 & 15.4 & 13.6 & 9.6 \\
\hline 15.0 & $\mathrm{CDD}$ & 350 & 84.2 & 43.5 & 23.8 & 21.5 & 17.6 & 13.3 & -- \\
\hline 20.0 & A & 377 & 69 & 25.0 & 16.6 & 15.7 & 13.6 & 10.7 & -- \\
\hline 20.0 & F & 393 & 48.8 & 26.9 & 15.5 & 14.9 & 13.6 & 10.7 & 6.7 \\
\hline 20.0 & B & 353 & 74.9 & 31.7 & 19.0 & 18.0 & 13.6 & 12.6 & -- \\
\hline 20.0 & $\mathrm{C}$ & 343 & -- & 36.0 & 17.5 & 17.6 & 14.9 & 11.0 & 7.1 \\
\hline
\end{tabular}

(a) Heat Treatments:

A. $1 \mathrm{hr}$ at $800 \mathrm{C}$, furnace cooled.

B. $1 \mathrm{hr}$ at $800 \mathrm{C}$, furnace cooled to $750 \mathrm{C}$; between $750 \mathrm{C}$ and $570 \mathrm{C}$ cooled at rate of $1 / 2 \mathrm{C}$ per min.

C. $1 \mathrm{hr}$ at $800 \mathrm{C}, 2 \mathrm{hr}$ at $550 \mathrm{C}$, water quench.

CDD. $1 \mathrm{hr}$ at $800 \mathrm{C}, 2 \mathrm{hr}$ at $550 \mathrm{C}$, water quenched; $5 \mathrm{~min}$ at $780 \mathrm{C}, 2 \mathrm{hr}$ at $550 \mathrm{C}$, and water quenched. Last step repeated.

E. $1 \mathrm{hr}$ at $800 \mathrm{C}$, furnace cooled to $670 \mathrm{C}$, held $24 \mathrm{hr}$, and furnace cooled.

F. $1 \mathrm{hr}$ at $800 \mathrm{C}$, water quenched, reheated to $670 \mathrm{C}$ for $24 \mathrm{hr}$, furnace cooled. 
TABLE 4. HOT HARDNESS OF URANIUM-MOLYBDENUM ALLOYS

\begin{tabular}{|c|c|c|c|c|c|c|c|c|c|}
\hline \multirow{2}{*}{$\begin{array}{c}\text { Molybdenum Content } \\
\text { (Balance Uranium), } \\
\text { w/o }\end{array}$} & \multirow{2}{*}{ Heat Treatment ${ }^{(a)}$} & \multicolumn{8}{|c|}{ Hardness, DPH, $\mathrm{kg}$ per $\mathrm{mm}^{2}$} \\
\hline & & Room & $600 \mathrm{C}$ & $650 \mathrm{C}$ & $680 \mathrm{C}$ & $700 \mathrm{C}$ & $725 \mathrm{C}$ & $750 \mathrm{C}$ & $800 \mathrm{C}$ \\
\hline 3.5 & $G$ & 260 & 15.4 & 4.4 & -- & 3.2 & - & 1.3 & 3.8 \\
\hline 3.5 & $\mathrm{H}$ & 438 & 31.0 & 9.2 & 11.7 & 10.8 & 9.2 & 6.1 & 4.4 \\
\hline 5.0 & $G$ & 119 & 26 & 19.0 & - & 13.2 & - & 9.3 & 7.5 \\
\hline 5.0 & $\mathrm{~J}$ & 397 & 14.3 & 12.5 & 11.4 & 11.1 & 9.6 & 8.6 & 7.1 \\
\hline 7.0 & $G$ & 248 & 34 & 35 & -- & 24 & -- & 17.4 & 14.8 \\
\hline 7.0 & $\mathrm{~K}$ & 448 & 47.2 & 38.1 & 34.0 & 31.4 & 23.9 & 20.6 & 13.3 \\
\hline 9.0 & G & 276 & 89 & 69 & -- & 51 & -- & 38 & 30 \\
\hline 9.0 & $\mathrm{~L}$ & 423 & 86.9 & 78.3 & 65.3 & 58.2 & 48.3 & 41.1 & 27.7 \\
\hline 12.0 & $G$ & 310 & 122 & 92 & - & 72 & $-\infty$ & 49 & $37: 0$ \\
\hline 12,0 & $\mathrm{M}$ & 312 & 158 & 112 & 105 & 93.0 & 78.8 & 67.4 & 47.4 \\
\hline
\end{tabular}

(a) Heat Treatment:

G. 1 hr at $800 \mathrm{C}$, water quenched.

H. 1 hr at $800 \mathrm{C}$, air cooled, specimen protected in an evacuated glass envelope.

J. 1 hr at $800 \mathrm{C}$, furnace cooled to $500 \mathrm{C}$, held $24 \mathrm{hr}$, furnace cooled.

K. $1 \mathrm{hr}$ at $800 \mathrm{C}$, furnace cooled to $500 \mathrm{C}$, held $100 \mathrm{hr}$, furnace cooled.

L. $1 \mathrm{hr}$ at $800 \mathrm{C}$, furnace cooled to $500 \mathrm{C}$, held $200 \mathrm{hr}$, furnace cooled.

M. 1 hr at $800 \mathrm{C}$, furnace cooled to $500 \mathrm{C}$, held 2 weeks, furnace cooled. 
The room-temperature hardnesses of transformed uraniummolybdenum alloys are greater than those of similar alloys containing retained-gamma structures. In addition, transformed uranium-3.5, 7, 9, and $12 \mathrm{w} / \mathrm{o}$ molybdenum alloys are harder, especially in the 650 to $750 \mathrm{C}$ range, than the same alloys when possessing retained-gamma structures. This condition does not exist in the uranium-5 w/o molybdenum alloy, as this alloy is harder with a retained-gamma structure.

Hardness curves plotted on semilog paper appear in the Appendix of this report. The curves are given for uranium-zirconium alloys in one condition of heat treatment, and for uranium-molybdenum alloys in two conditions of heat treatment.

\section{LINEAR THERMAL EXPANSION}

The linear thermal expansion of uranium-zirconium and uraniummolybdenum alloys was studied in the temperature range of 20 to $950 \mathrm{C}$. Measurements were obtained by means of a recording quartz-tube dilatometer upon specimens protected by a vacuum of approximately $2 \times 10^{-5}$ $\mathrm{mm}$ of mercury. The maximum heating and cooling rates to which specimens were subjected were about $5 \mathrm{C}$ per min. In most cases only one thermal cycle was run. However, a second thermal cycle was used as a check on a few specimens.

Table 5 lists heating and cooling information obtained on specimens of both alloys between 20 and $950 \mathrm{C}$. Temperatures at the beginning and end of the transformations are given where detected. As transformation of uranium-molybdenum alloys became sluggish with increased molybdenum content, dilation-curve transformations were not detected on all specimens.

A few general characteristics were noted concerning dilation of uranium-zirconium and uranium-molybdenum alloys. They are mentioned in the following paragraphs.

Transformations were detected on all specimens of uranium-zirconium regardless of prior heat treatment and were easily detected both in the heating and cooling cycles. It appeared that thermal expansion was more a function of zirconium content than of heat treatment, as expansion of the same order of magnitude occurred in a given composition in both heat-treated conditions studied. 
All uranium-zirconium specimens were reduced in length slightly as a result of having been cycled to $950 \mathrm{C}$. This is recorded on the dilation graphs by the cooling curve which falls below the base line. Increased zirconium in uranium caused decreased total linear expansion. In addition, a greater transformation-temperature span was produced by an increase in zirconium content. The last-mentioned phenomenon is most pronounced in the uranium -15 and $20 \mathrm{w} / \mathrm{o}$ zirconium alloys.

Dilation of uranium-molybdenum alloys was measured in two conditions of heat treatment. Included were alloys both gamma quenched and partially transformed. The results are shown in Table 5 and by graphs included in the Appendix.

Transformation was detected only upon uranium-3. 5 and $5 \mathrm{w} / \mathrm{o}$ molybdenum gamma-quenched alloys. However, when soaked for a period of time at $500 \mathrm{C}$, uranium-7 and $9 \mathrm{w} / 0$ molybdenum specimens were observed to transform during the heating cycle. Whenever transformation was detected in uranium-molybdenum alloys, it was accompanied by a slight increase in specimen length. Where transformation was not detected, the specimens decreased slightly in length upon cycling to $950 \mathrm{C}$. Over-all contraction of uranium-molybdenum alloys was less than that occurring in uranium-zirconium alloys.

\section{THERMAL CYCLING}

Cylinders of the uranium-zirconium and uranium-molybdenum alloys under investigation were thermal cycled to determine their relative thermal stabilities. The cylinders, measuring approximately 1.00 in. long and $0.425 \mathrm{in}$. in diameter, were sealed in individual Vycor capsules under a partial pressure of argon.

Uranium-zirconium specimens were cycled at two temperatures: between 150 and $680 \mathrm{C}$, and between 150 and $725 \mathrm{C}$. The uraniummolybdenum alloys were cycled only at the higher temperature. Time required for completing one 150 to $725 \mathrm{C}$ cycle was approximately $25 \mathrm{~min}$.

The uranium-zirconium alloys withstood cycling well between 150 and $680 \mathrm{C}$. Even when cycled for more than 500 times, specimens were observed to have changed less than 0.1 per cent in length per 100 thermal cycles. In addition, surface condition and appearance of the specimens were good. It appeared that specimens containing the greater zirconium contents were least affected by cycling deformation. 
TABLE 5. LINEAR THERMAL EXPANSION OF URANIUM-

Nominal Composition

(Balance Uranium),

Heat

Coefficient of Linear Expansion $\times 10^{6}$ Over Tem w/o

Treatment $t^{(a)}$ Cycles $20-100 \quad 20-200 \quad 20-300 \quad 20-400$ $20-500 \quad 20-600 \quad 20-700$

3. $5 \mathrm{Mo}$

G

$$
2
$$

10.85

12.64

13.71

14.47

15.19

16.27

21.50

13.29

3. $5 \mathrm{Mo}$

$\mathrm{H}$

2

11.90

13.38

14.42

15.17

15.97

22.15

14.4

14.30

14.99

15.78

.16 .74

$5.0 \mathrm{Mo}$

G

3

13.20

14.15

14.07

14.80

$15.32 \quad 15.96$

21.79

$5.0 \mathrm{Mo}$

J

1

$\begin{array}{lll}11.64 & 13.18 & 14.13\end{array}$

12.85

13.78

14.38

$16.26 \quad 16.56$

17.08

21.06

(5)

G

1

10.43

12.78

11.26

12.42

14.91

16.59

19.96

19.81

7. $0 \mathrm{Mo}$

K

$1 \quad 12.2$

9. $0 \mathrm{Mo}$

G

1

$$
12.88
$$

11.80

L

1

9.99

11.86

13.

13

. 66

14.66
14.91

15.30

20.54

$9.0 \mathrm{Mo}$

G

2

$8.95 \quad 10.45$

11. 34

13.42
12.09

47

14.13

13.09

13.60

14.23

14.18

14.88

14.73

$14.87 \quad 15.66$

$13.60 \quad 13.88$

16.37

14.38

19.97

12. $0 \mathrm{Mo}$

12. 0Mo

M

1

$13.76 \quad 13.75$

11.74

11.49

$2 \quad 14.11$

14.68
13.61

15.22

15.74

4.52

16.07

5.04

$3.0 \mathrm{Zr}$

$3.0 \mathrm{Zr}$

E

2

13.49

14.70

12.46

12.63

13.36

14.05

13.56

14.08

14.57

16.92

15.09

$3.0 \mathrm{Zr}$

CDD

1

$\begin{array}{lll}13.63 & 14.83 & 15.44\end{array}$

12.11

12.56

13.08

13.56

12.22

12.73

13.19

13.6

14.14

$5.0 \mathrm{Zr}$

5. $0 \mathrm{Zr}$

E

1

13.

CDD

1

11.5
13.5

1

$\begin{array}{lll}10.24 & 11.89 & 13.52 \\ 13.03 & 13.66 & 14.19\end{array}$

14.11

14.25

14.41

14.59

14.01

13.34

13.82

14.23

14.75

$5.0 \mathrm{Zr}$

E

$7.0 \mathrm{Zr}$

$\begin{array}{ll}14.48 & 15.18 \\ 15.21 & 15.70 \\ & \\ 14.83 & 15.44 \\ 15.27 & 15.78\end{array}$

$\begin{array}{lll}15.91 & 16.74 & 17.83\end{array}$

$16.65 \quad 17.69 \quad 19.13$

$\begin{array}{lll}15.92 & 16.62 & 17.89\end{array}$

$\begin{array}{lll}16.58 & 17.70 & 19.90\end{array}$

$\begin{array}{lll}13.57 & 14.53\end{array}$

$15.22 \quad 16.07 \quad 17.15$

$\begin{array}{lll}15.22 & 16.07 & 17.1 \\ 16.18 & 17.22 & 18.58\end{array}$

$\begin{array}{lll}.38 & 13.57 & 14.53 \\ .46 & 15.11 & 15.53\end{array}$

18.58

26.50

$13.03 \quad 13.66$


ZIRCONIUM AND URANIUM-MOLYBDENUM ALLOYS

\begin{tabular}{|c|c|c|c|c|c|c|c|}
\hline \multicolumn{4}{|c|}{ perature, $C$, Ranges Shown } & $\begin{array}{l}\text { Temper ature at } \\
\text { Beginning of } \\
\text { Transformation, } \\
\text { C }\end{array}$ & $\begin{array}{l}\text { Coefficient } x 10^{6} \\
\text { at Beginning of } \\
\text { Transformation }\end{array}$ & $\begin{array}{c}\text { Temperature at } \\
\text { Finish of } \\
\text { Transformation, } \\
\text { C }\end{array}$ & $\begin{array}{c}\text { Coefficient } \times 10^{6} \\
\text { at Finish of } \\
\text { Transformation }\end{array}$ \\
\hline 21.36 & 21.36 & 21.43 & & 600 & 16.27 & 680 & 21.46 \\
\hline 22.01 & 21.98 & 21.98 & & 575 & 17.50 & 605 & 22.29 \\
\hline 21.80 & 21.66 & 21.64 & & 625 & 17.60 & 685 & 21.90 \\
\hline 21.71 & 21.77 & 21.81 & & 550 & 16.88 & 625 & 21.96 \\
\hline 20.84 & 20.85 & 20.87 & & 625 & 17.99 & 675 & 21.08 \\
\hline 19.87 & 20.08 & 20.15 & & 500 & 16.59 & 565 & 19.95 \\
\hline 20.29 & 20.27 & 20.28 & & 575 & 15.79 & 650 & 20.53 \\
\hline 19.81 & 20.02 & 20.06 & & 445 & 15.51 & 575 & 19.83 \\
\hline 15.78 & 16.17 & 16.24 & & & & & \\
\hline 16.45 & 17.04 & 17.34 & & & & & \\
\hline 19.74 & 19.70 & 19.76 & & 600 & 16.37 & 665 & 20.02 \\
\hline 15.67 & 16.14 & 16.37 & & & & & \\
\hline 16.27 & 16.39 & 16.36 & & & & & \\
\hline 15.71 & 16.40 & 16.74 & & & & & \\
\hline 17.13 & 17.44 & 17.51 & & 595 & 14.44 & 650 & 16.14 \\
\hline 15.62 & 16.26 & 16.51 & & & & & \\
\hline 14.14 & 14.71 & - & 15.25 & & & & \\
\hline 14.69 & 15.27 & -- & 15.90 & & & & \\
\hline 14.82 & 15.26 & 15.49 & & & & & \\
\hline 15.28 & 15.89 & 16.25 & & & & & \\
\hline 24.39 & 23.95 & 23.83 & & 680 & 19.46 & 750 & 24.63 \\
\hline 25.59 & 25.33 & 25.21 & & 650. & 20.15 & 680 & 26.36 \\
\hline 22.79 & 22.57 & 22.56 & & 685 & 19.42 & 720 & 23.11 \\
\hline 25.59 & 25.24 & 25.12 & & 660 & 20.30 & 680 & 26.19 \\
\hline 23.17 & 22.90 & 22.84 & & 685 & 19.00 & 725 & 23.48 \\
\hline 25.95 & 25.53 & 25.40 & & 650 & 19.70 & 675 & 226.73 \\
\hline 23.73 & 23.23 & 23.10 & & 695 & 19.23 & 715 & 24.46 \\
\hline 25.46 & 25.17 & 25.04 & & 650 & 19.45 & 670 & 26.17 \\
\hline 22.08 & 21.51 & 21.38 & & 690 & 18.89 & 720 & 22.88 \\
\hline 24.28 & 24.13 & 24.08 & & 655 & 18.81 & 670 & 24.82 \\
\hline
\end{tabular}


TABLE 5.

\begin{tabular}{|c|c|c|c|c|c|c|c|c|c|}
\hline \multirow{2}{*}{$\begin{array}{c}\text { Nominal Composition } \\
\text { (Balance Uranium), } \\
\text { w/o }\end{array}$} & \multirow{2}{*}{$\begin{array}{l}\text { Heat } \\
\text { Treatment(a) }\end{array}$} & \multirow[b]{2}{*}{ Cycles } & \multicolumn{7}{|c|}{ Coefficient of Linear Expansion $\times 10^{6}$ Over Tem- } \\
\hline & & & $20-100$ & $20-200$ & $20-300$ & $20-400$ & $20-500$ & $20-600$ & $20-700$ \\
\hline \multirow[t]{2}{*}{$7.0 \mathrm{Zr}$} & CDD & 1 & 11.29 & 12.58 & 13.81 & 14.31 & 15.06 & 16.25 & \\
\hline & & & 12.38 & 13.25 & 13.85 & 14.45 & 15.41 & 16.85 & 24.29 \\
\hline \multirow[t]{2}{*}{$10.0 \mathrm{Zr}$} & $\mathbf{E}$ & 1 & 10.51 & 12.02 & 13.57 & 14.85 & 15.69 & 16.43 & \\
\hline & & & 13.83 & 13.91 & 13.94 & 14.33 & 15.24 & 16.66 & 24.45 \\
\hline \multirow[t]{2}{*}{$10.0 \mathrm{Zr}$} & B & 1 & 13.88 & 14.26 & 15.12 & 15.82 & 16.41 & 17.17 & \\
\hline & & & 12.38 & 13.03 & 13.37 & 13.96 & 14.94 & 16.32 & 24.00 \\
\hline \multirow[t]{2}{*}{$15.0 \mathrm{Zr}$} & B & 1 & 12.20 & 11.73 & 12.90 & 13.79 & 14.59 & 15.41 & 19.58 \\
\hline & & & 10.70 & 11.71 & 12.38 & 13.02 & 14.00 & 15.42 & 21.45 \\
\hline \multirow[t]{2}{*}{$15.0 \mathrm{Zr}$} & $\mathbf{E}$ & 1 & 10.79 & 11.51 & 12.54 & 13.33 & 14.31 & 15.20 & \\
\hline & & & 10.44 & 11.25 & 11.80 & 12.67 & 13.73 & 15.04 & 20.86 \\
\hline \multirow[t]{2}{*}{$20.0 \mathrm{Zr}$} & $\mathrm{C}$ & 2 & 10.26 & 11.09 & 12.04 & 12.68 & 13.43 & 14.42 & \\
\hline & & & 10.04 & 10.72 & 11.30 & 11.97 & 12.91 & 14.22 & 18.35 \\
\hline \multirow[t]{2}{*}{$20.0 \mathrm{Zr}$} & B & 2 & 9.30 & 10.60 & 11.48 & 12.17 & 12.90 & & \\
\hline & & & 10.08 & 11.04 & 11.60 & 12.45 & 13.43 & 14.62 & 18.32 \\
\hline
\end{tabular}

Note: The first row of coefficients, opposite the specimen, are from the heating curve and the second row are from the cooling curve.

(a) Heat Treatments:

G. $1 \mathrm{hr} 800 \mathrm{C}$, water quenched.

H. $1 \mathrm{hr} 800 \mathrm{C}$, air cooled, specimen protected in evacuated glass envelope.

J. $1 \mathrm{hr} 800 \mathrm{C}$, furnace cooled to $500 \mathrm{C}$, held $24 \mathrm{hr}$, furnace cooled.

K. $1 \mathrm{hr} 800 \mathrm{C}$, furnace cooled to $500 \mathrm{C}$, held $100 \mathrm{hr}$, furnace cooled.

L. $1 \mathrm{hr} 800 \mathrm{C}$, furnace cooled to $500 \mathrm{C}$, held $200 \mathrm{hr}$, furnace cooled.

M. $1 \mathrm{hr} 800 \mathrm{C}$, furnace cooled to $500 \mathrm{C}$, held 2 weeks, furnace cooled.

C. $1 \mathrm{hr} 800 \mathrm{C}$, isothermally transformed $550 \mathrm{C}$ for $2 \mathrm{hr}$, water quenched.

E. $1 \mathrm{hr} 800 \mathrm{C}$, held $24 \mathrm{hr} 670 \mathrm{C}$, furnace cooled.

CDD. $1 \mathrm{hr} 800 \mathrm{C}$, isothermally transformed $2 \mathrm{hr} 550 \mathrm{C}$; plus $5 \mathrm{~min} 780 \mathrm{C}$, isothermally transformed $2 \mathrm{hr} 550 \mathrm{C}$, plus repeat $5 \mathrm{~min} 780 \mathrm{C}, 2 \mathrm{hr} 550 \mathrm{C}$.

B. $1 \mathrm{hr} 800 \mathrm{C}$, furnace cooled to $750 \mathrm{C}$, furnace cooled from $750 \mathrm{C}$ to $570 \mathrm{C}$ at $1 / 2 \mathrm{C}$ per min. 
(Continued)

\begin{tabular}{|c|c|c|c|c|c|c|c|}
\hline \multicolumn{4}{|c|}{ perature, $C$, Ranges Shown } & $\begin{array}{l}\text { Temperature at } \\
\text { Beginning of } \\
\text { Transformation, } \\
\text { C }\end{array}$ & $\begin{array}{l}\text { Coefficient } \times 10^{6} \\
\text { at Beginning of } \\
\text { Transformation }\end{array}$ & $\begin{array}{l}\text { Temperature at } \\
\text { Finish of } \\
\text { Transformation, } \\
\text { C }\end{array}$ & $\begin{array}{c}\text { Coefficient } \times 10^{6} \\
\text { at Finish of } \\
\text { Transformation }\end{array}$ \\
\hline 21.57 & 20.77 & 20.46 & & 690 & 18.49 & 710 & 22.65 \\
\hline 23.92 & 23.73 & 23.64 & & 650 & 18.50 & 670 & 24.47 \\
\hline 22.90 & 22.08 & 21.78 & & 690 & 19.15 & 720 & 23.59 \\
\hline 24.17 & 24.00 & 23.96 & & 645 & 18.57 & 665 & 24.27 \\
\hline 23.47 & 22.87 & 22.64 & & 685 & 19.64 & 725 & 24.09 \\
\hline 23.69 & 23.53 & 23.46 & & 645 & 18.27 & 665 & 23.79 \\
\hline 19.63 & 19.18 & 19.06 & & 625 & 15.88 & 700 & 19.58 \\
\hline 22.18 & 21.55 & 21.64 & & 600 & 15.42 & 665 & 20.82 \\
\hline 19.73 & 19.24 & 18.95 & & 630 & 15.73 & 730 & 19.80 \\
\hline 20.86 & 20.92 & 21.03 & & 610 & 15.21 & 690 & 20.79 \\
\hline 17.56 & 17.47 & 17.41 & & 625 & 14.81 & 710 & 17.40 \\
\hline 18.51 & 18.63 & 18.64 & & 600 & 14.22 & 680 & 18.29 \\
\hline 16.65 & 16.37 & 16.19 & & 620 & 14.08 & 720 & 16.74 \\
\hline 18.38 & 18.50 & 18.60 & & 600 & 14.62 & 665 & 18.30 \\
\hline
\end{tabular}


The uranium-zirconium specimens were also cycled between 150 and $725 \mathrm{C}$. When examined after 60 cycles, specimens of lower zirconium contents showed evidence of surface roughening and blistering. This condition continued upon subsequent cycling. Specimens of higher zirconium content were also affected as the number of thermal cycles was increased. At the end of 250 cycles, roughening and distortion had occurred in specimens of uranium -3 through $10 \mathrm{w} / \mathrm{o}$ zirconium to the extent that accurate measurements could not be obtained. The surface of the uranium-15 and $20 \mathrm{w} / \mathrm{o}$ zirconium specimens was smooth but had become symmetrically distorted as a result of cycling. Figure $8 \mathrm{a}$ shows a uranium-10 w/o zirconium specimen cycled 530 times between 150 and $680 \mathrm{C}$. It is only slightly affected by thermal cycling. Figure $8 \mathrm{~b}$ shows the same composition cycled 235 times between 150 and $725 \mathrm{C}$. Both specimens were machined from the same material and both received the same heat treatment. The distortion present in the specimen in Figure $8 \mathrm{~b}$ is a result of cycling beyond the alpha-beta transformation.

Uranium-molybdenum alloys were thermally cycled in two conditions of heat treatment. The specimens were examined after 250 and 530 cycles, respectively. At the end of 530 cycles, the specimens were examined for deformation and growth. All of the specimens appeared little affected by cycling, with the exception of uranium-3.5 w/o molybdenum. This specimen was surface roughened and distorted, and appeared to be breaking down. The remainder of the cylinders possessed smooth surfaces and a good appearance. Change in length and diameter of these specimens was less than 0.1 per cunt per 100 cycles.

Figure 9a shows a uranium-3.5 w/o molybdenum specimen after 530 cycles. Figure $9 \mathrm{~b}$ shows a specimen of uranium-7.0 w/o molybdenum cycled the same amount. The clean appearance of the uranium-7 w/o molybdenum specimen is typical of specimens of higher molybdenum content after cycling 500 times.

\section{CONCLUSIONS}

On the basis of physical-property determinations listed in this report, primary uranium alloys containing 5 through $12 \mathrm{w} / 0$ molybdenum appear promising as potential reactor fuels. The alloys are more thermally stable at temperatures above $680 \mathrm{C}$ than comparable uranium-zirconium alloys. In addition, hot-hardness values obtained between 600 and $800 \mathrm{C}$ indicate that the uranium-molybdenum alloys possess greater elevated-temperature strengths than the zirconium alloys. 


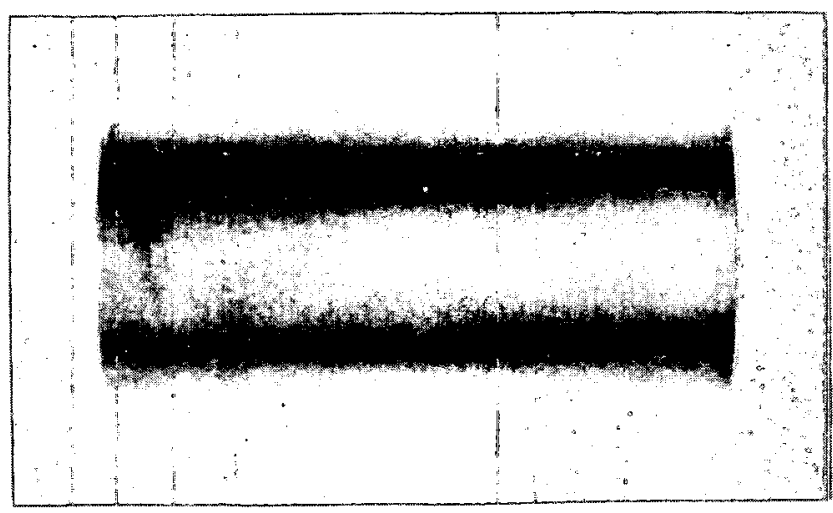

$2-1 / 2 \mathrm{X}$

N29523

a. Cycled 530 Times Between 150 and $680 \mathrm{C}$

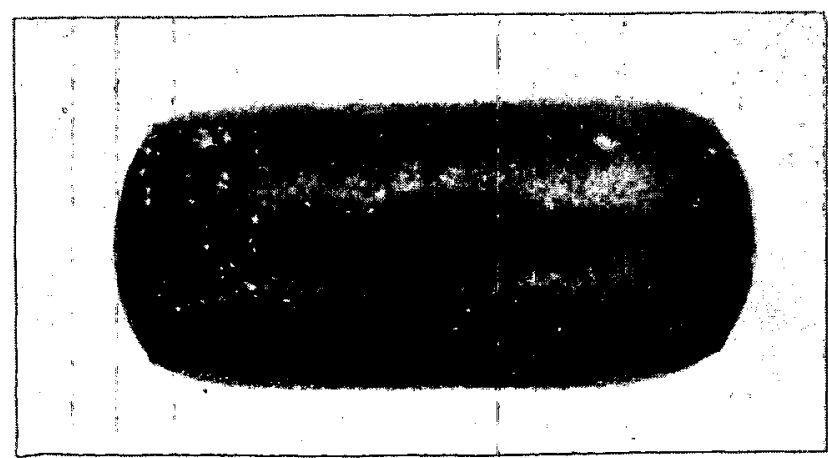

$2-1 / 2 \mathrm{X}$

N29524

b. Cycled 235 Times Between 150 and $725 \mathrm{C}$

FIGURE 8. URANIUM-10 w/O ZIRCONIUM THERMALLY CYCLED AS INDICATED

Specimens were furnace cooled from $800 \mathrm{C}$. 


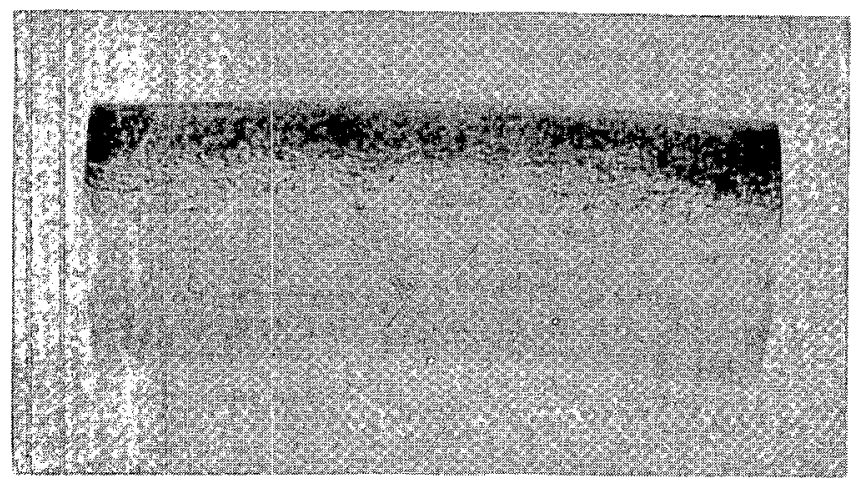

$2-1 / 2 \mathrm{X}$

N29525

a. Uranium-3.5 w/o Molybdenum

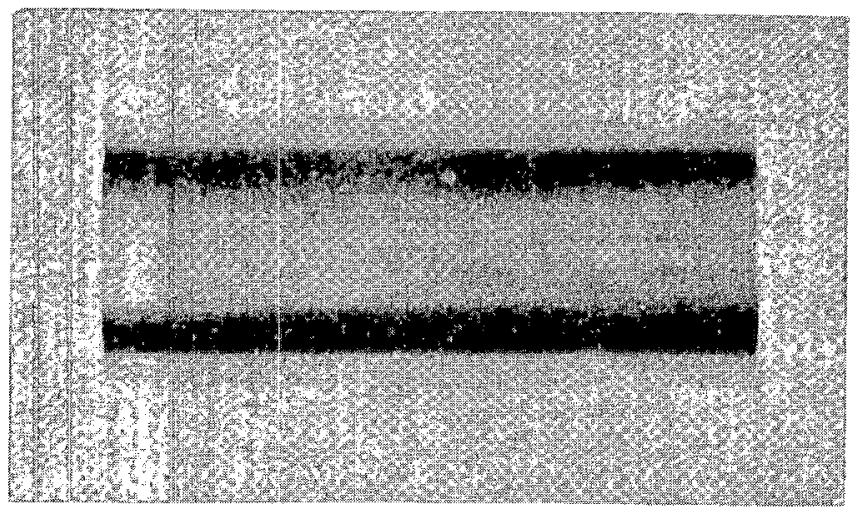

$2-1 / 2 \mathrm{X}$

N29526

b. Uranium-7 w/o Molybdenum

FIGURE 9. URANIUM-MOLYBDENUM SPECIMENS CYCLED 530 TIMES BET WEEN 150 AND $725 \mathrm{C}$

Specimens were water quenched from $800 \mathrm{C}$. 
Binary uranium-zirconium alloys below $15 \mathrm{w} / 0$ zirconium were shown to have poor thermal stability above $680 \mathrm{C}$. However, alloys containing 15 and $20 \mathrm{w} / 0$ zirconium possessed a degree of stability and an elevatedtemperature hardness sufficient to warrant further study concerning their use as reactor fuels.

Studies are in progress to obtain elevated-temperature mechanical properties on both uranium-molybdenum and uranium-zirconium alloys. This information will be reported as it becomes available. 


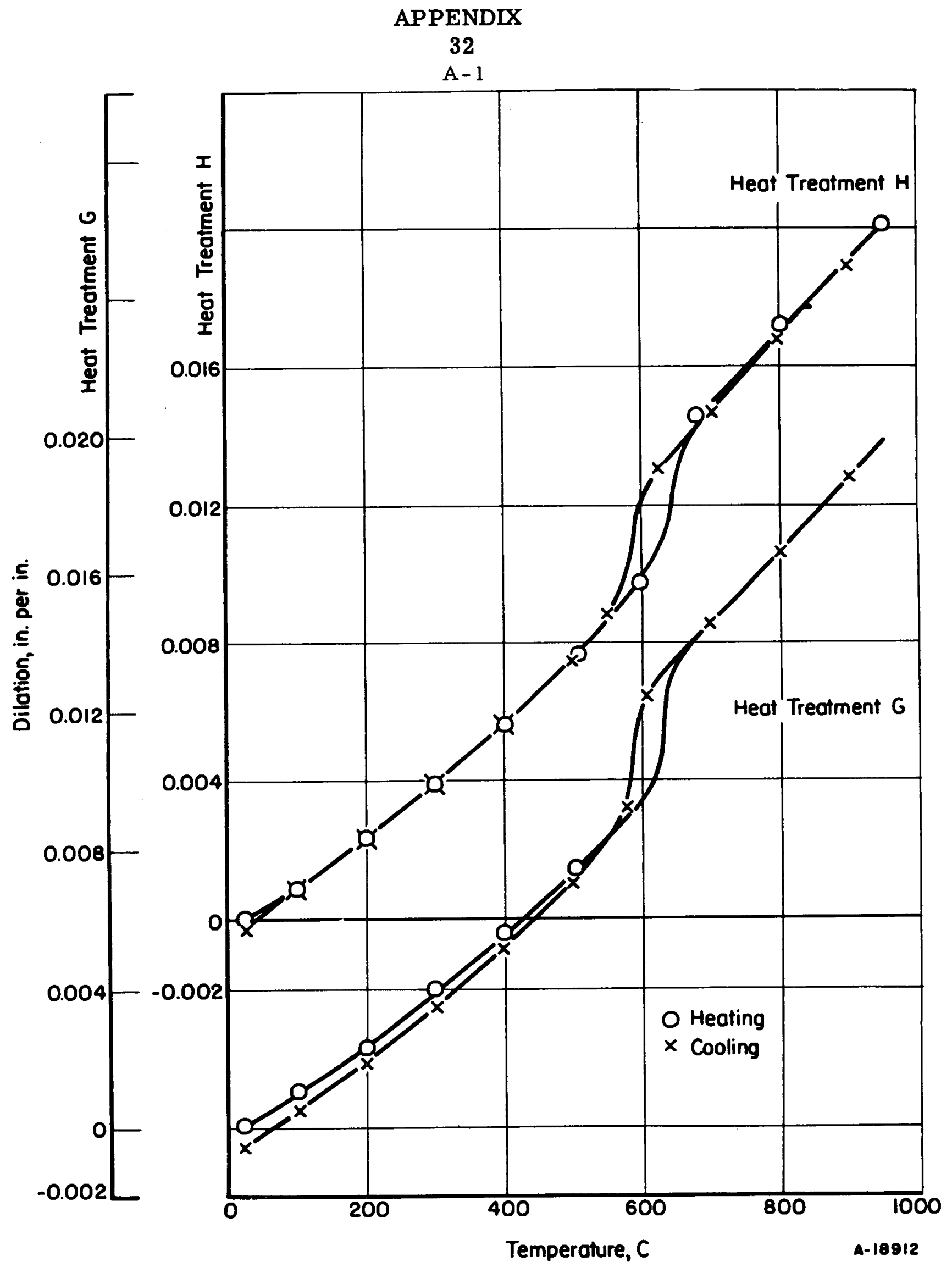

FIGURE A-1. LINEAR THERMAL EXPANSION VERSUS TEMPERATURE FOR URANIUM-3.5 w/O MOLYBDENUM 


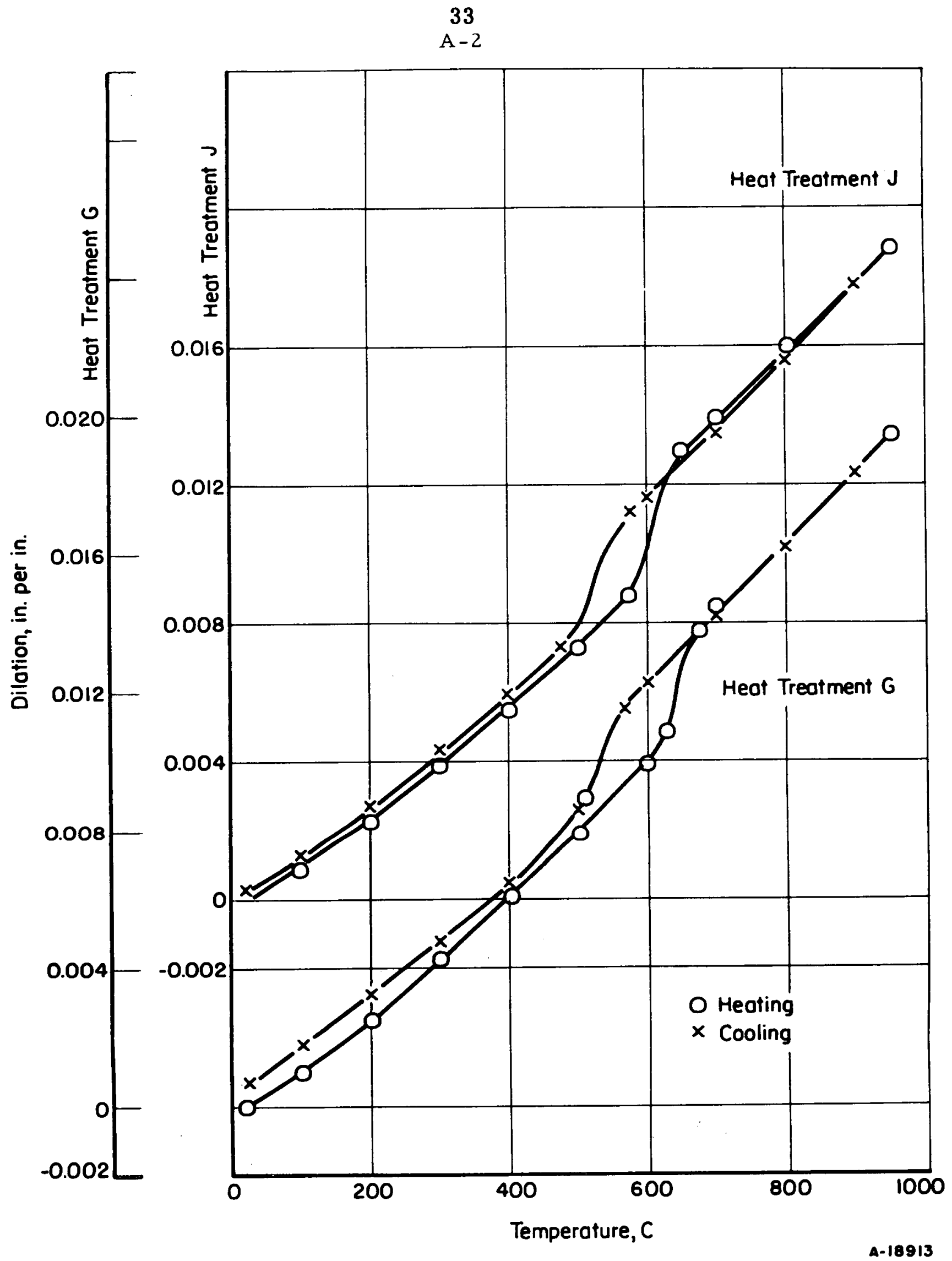

FIGURE A-2. LINEAR THERMAL EXPANSION VERSUS TEMPERATURE FOR URANIUM-5.0 w/O MOLYBDENUM 
A -3

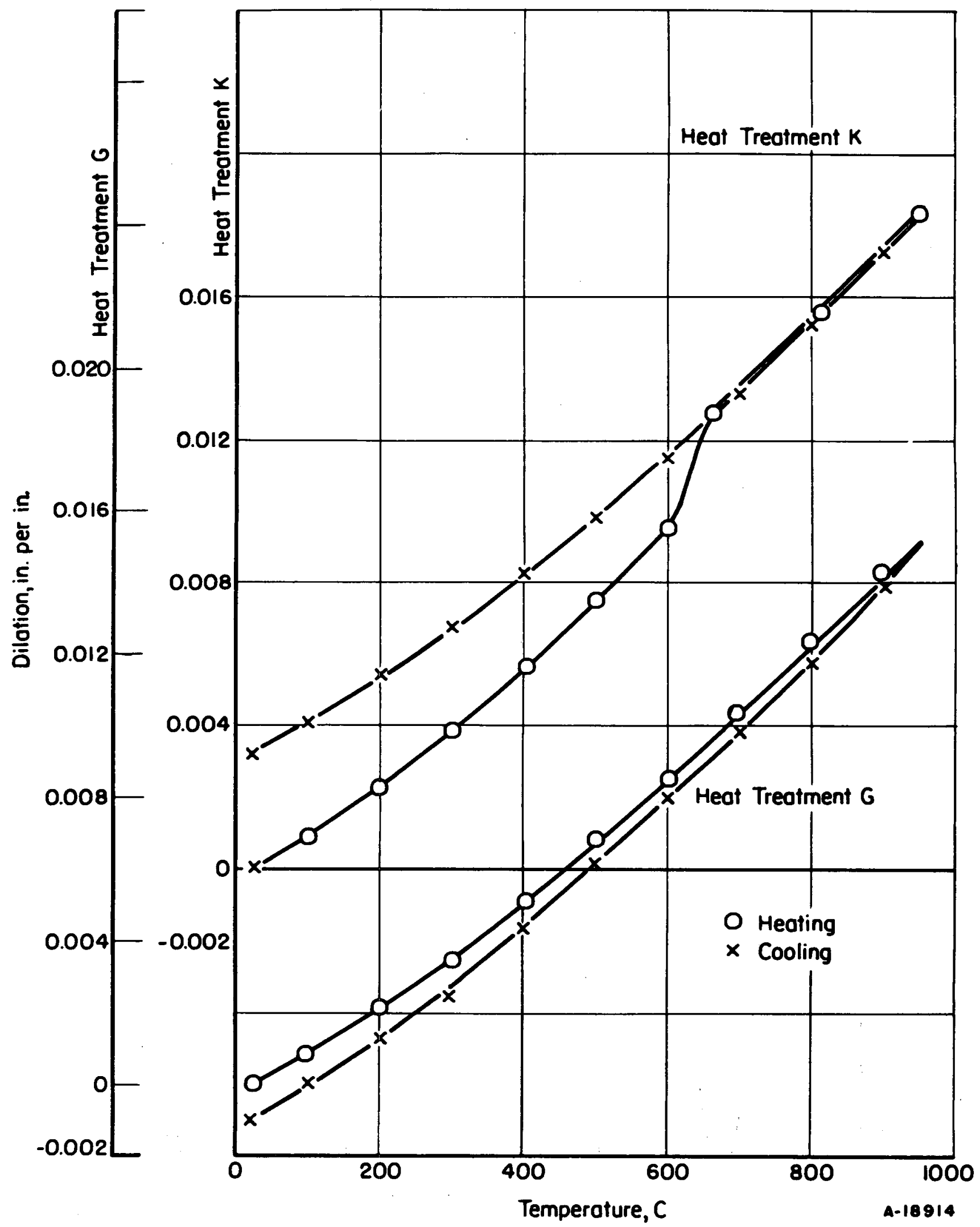

FIGURE A-3. LINEAR THERMAL EXPANSION VERSUS TEMPERATURE FOR URANIUM-7.0 w/O MOLYBDENUM 


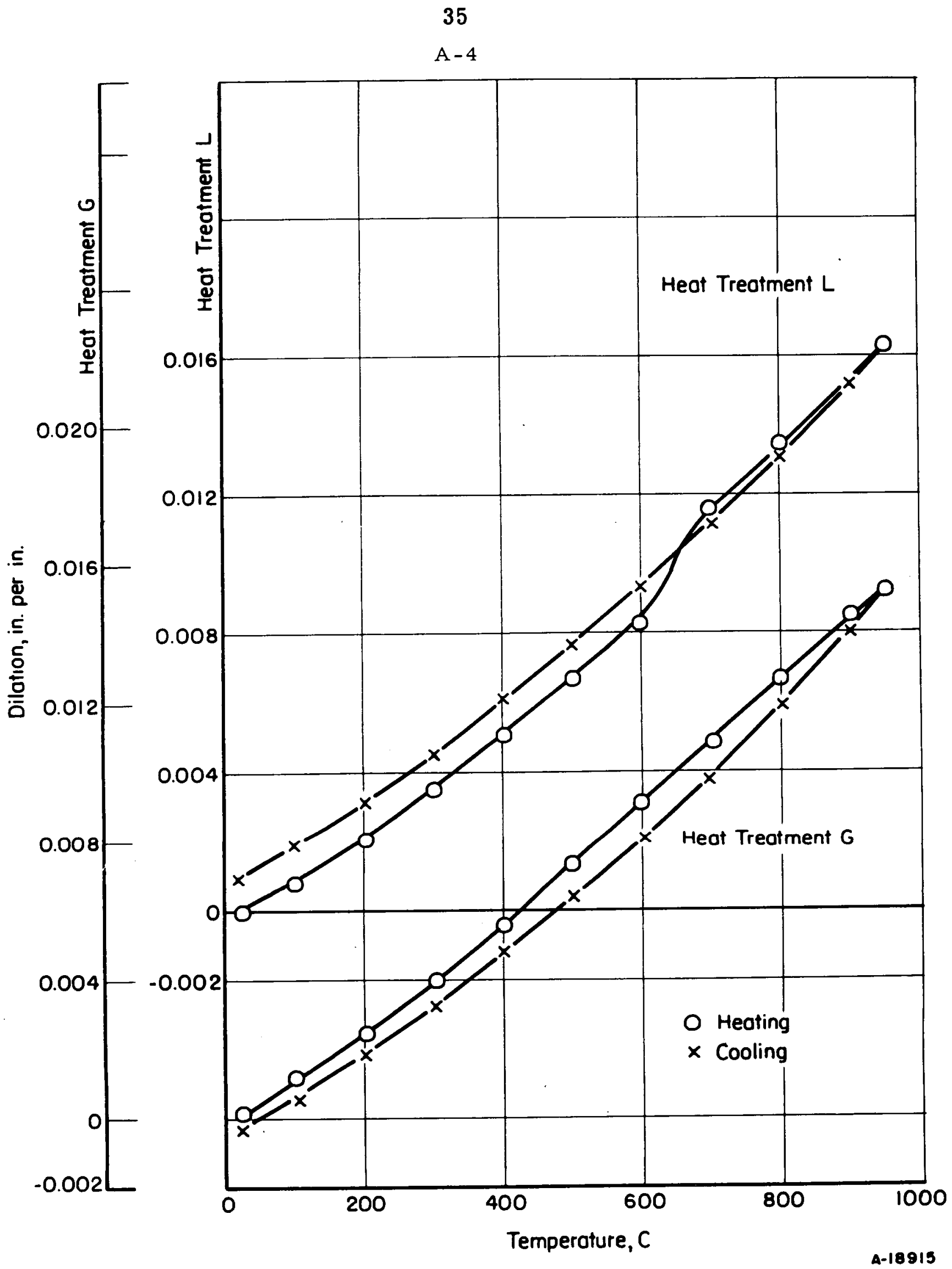

FIGURE A-4. LINEAR THERMAL EXPANSION VERSUS TEMPERATURE FOR URANIUM-9.0 w/O MOLYBDENUM 
A -5

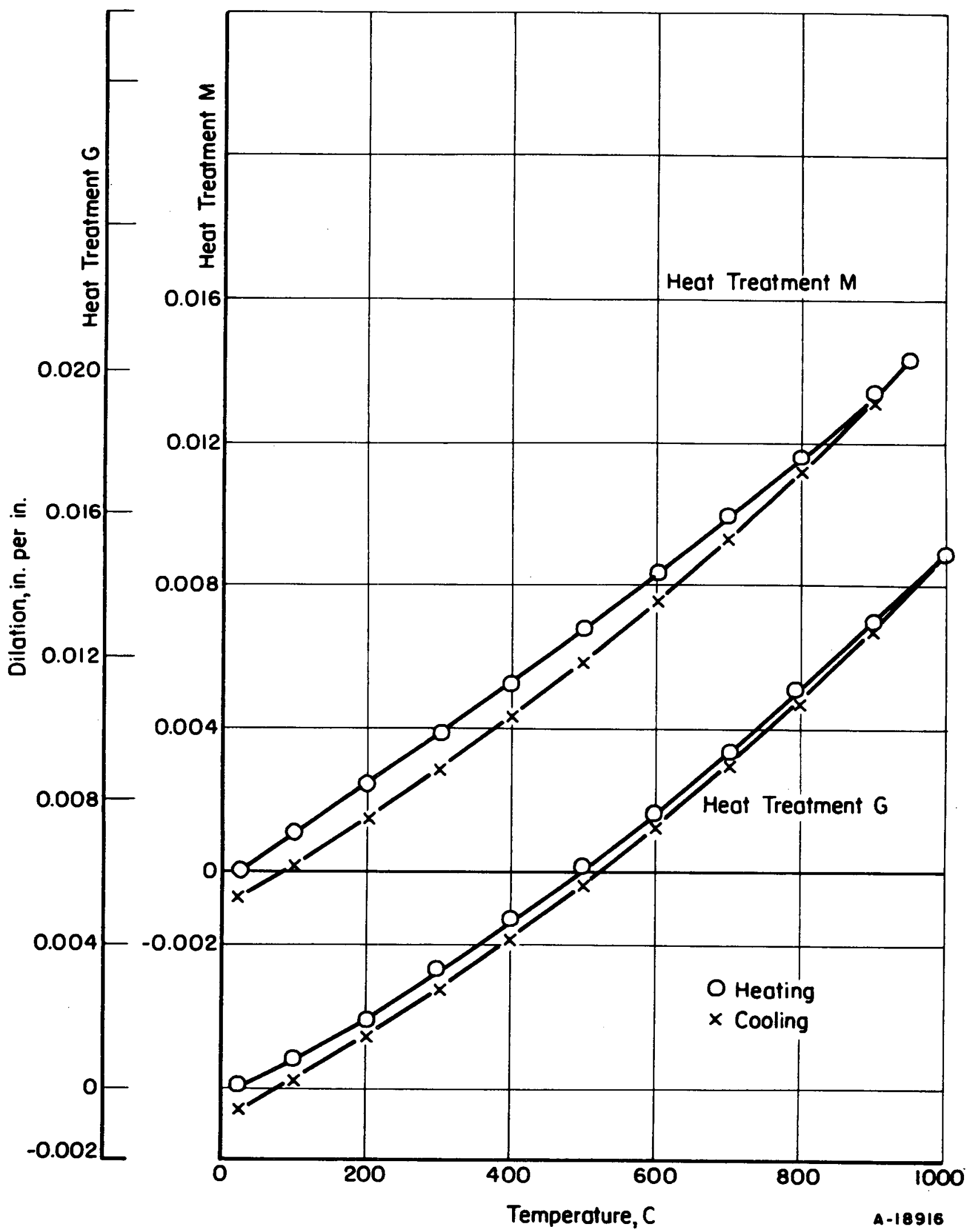

FIGURE A-5. LINEAR THERMAL EXPANSION VERSUS TEMPERATURE FOR URANIUM-12.0 w/O MOLYBDENUM 


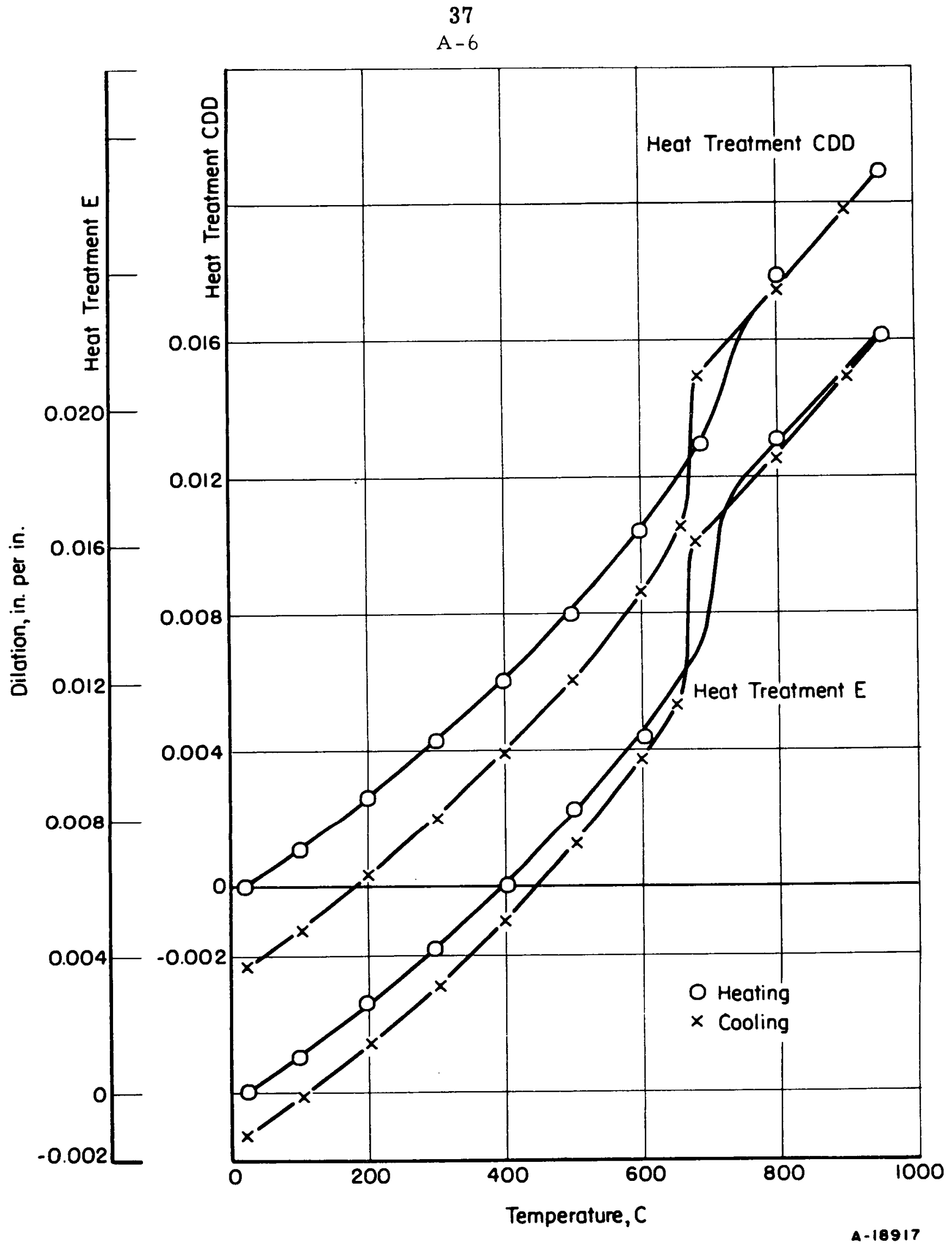

FIGURE A-6. LINEAR THERMAL EXPANSION VERSUS TEMPERATURE FOR URANIUM-3.0 w/O ZIRCONIUM 


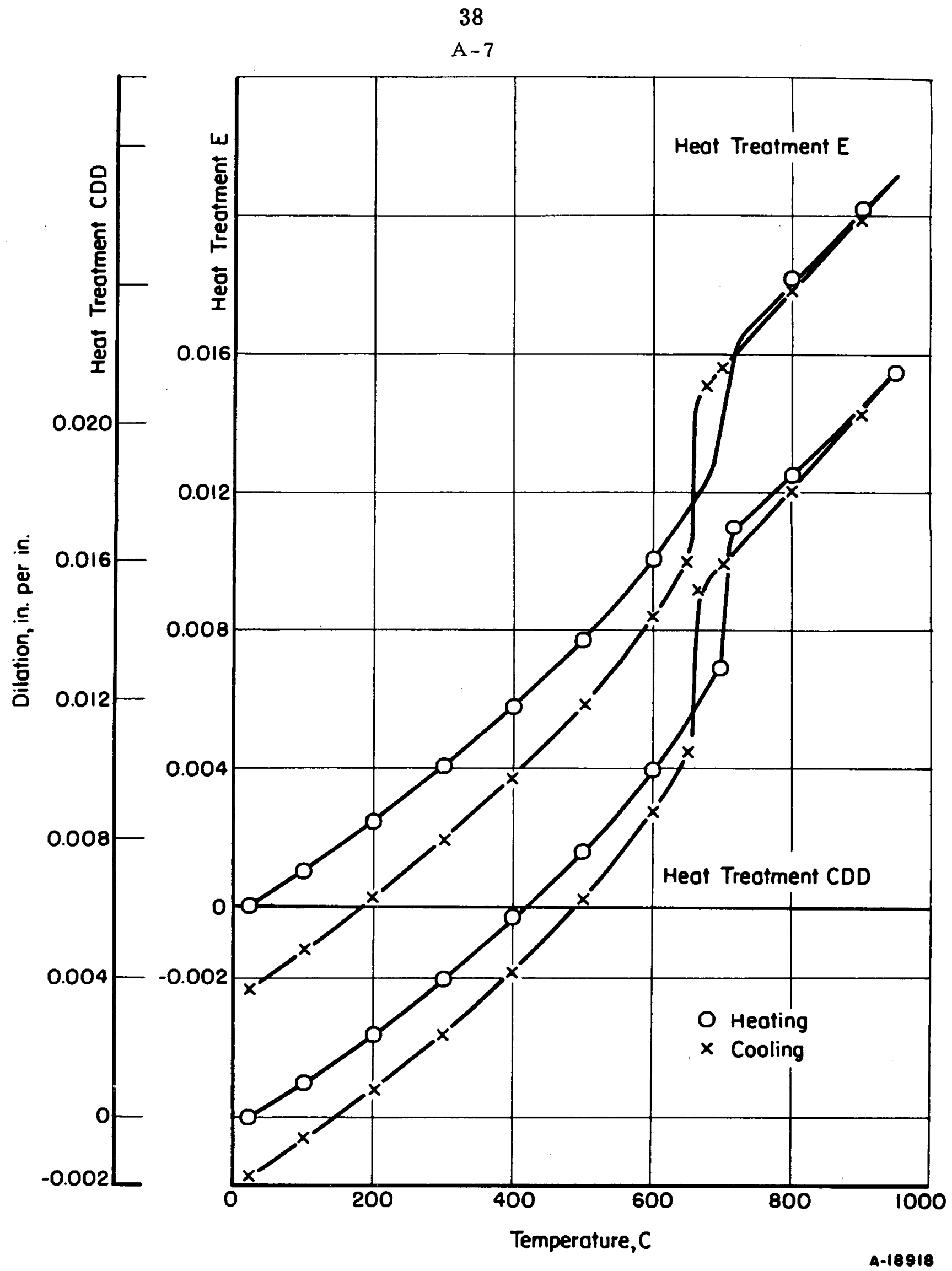

FIGURE A-7. LINEAR THERMAL EXPANSION VERSUS TEMPERATURE FOR URANIUM $-5.0 \mathrm{w} / \mathrm{O}$ ZIRCONIUM 


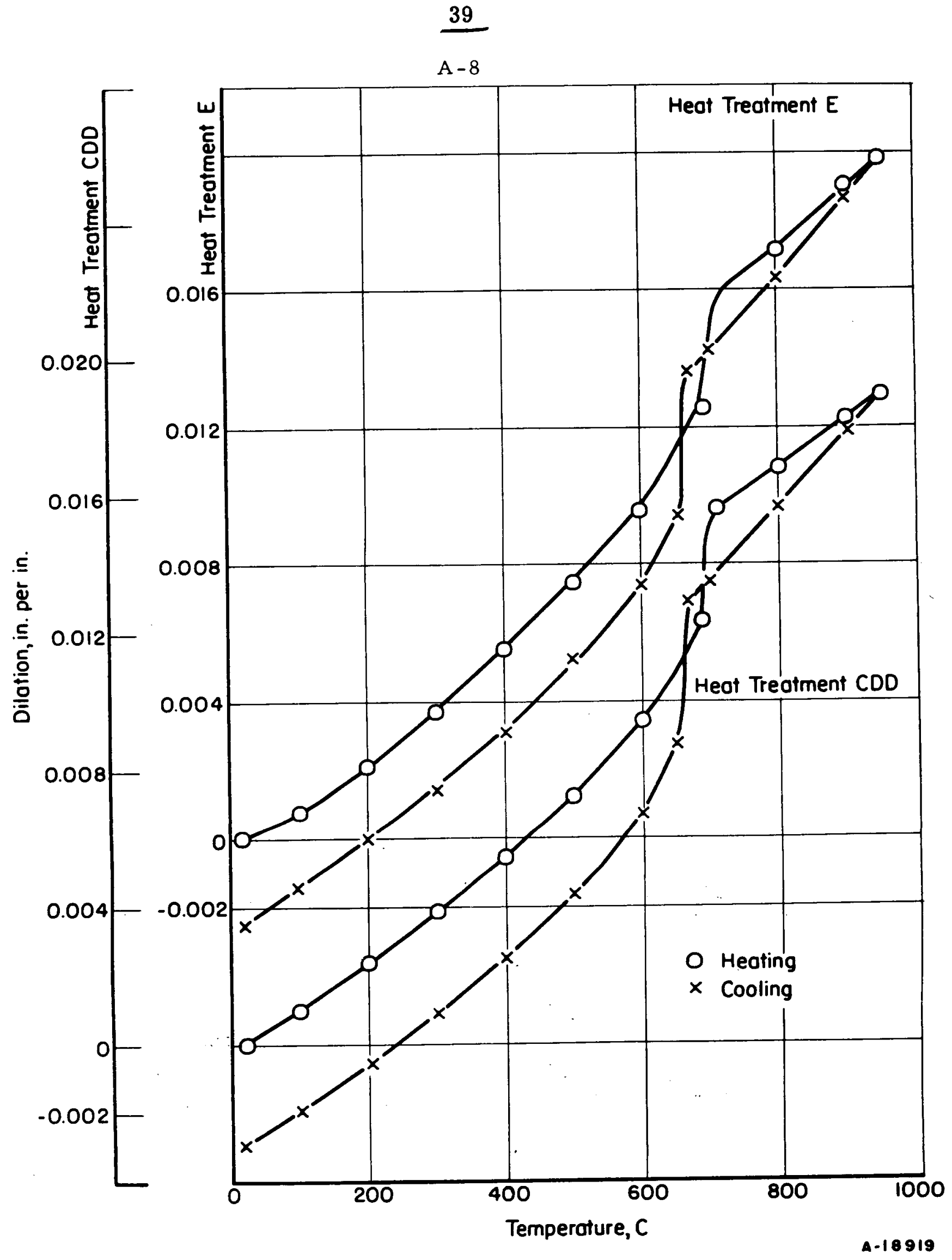

FIGURE A-8. LINEAR THERMAL EXPANSION VERSUS TEMPERATURE FOR URANIUM-7.0 w/O ZIRCONIUM 


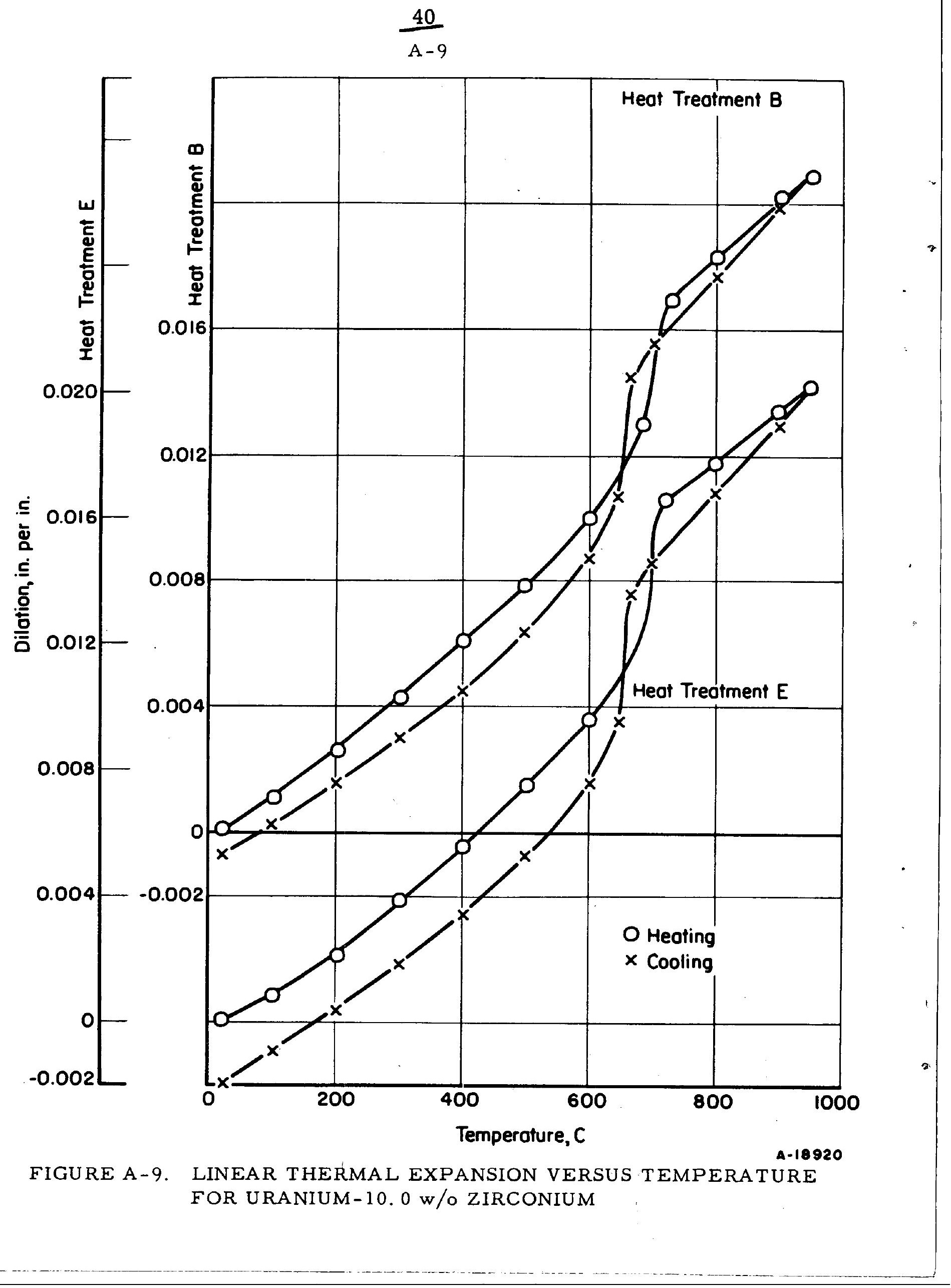


A -10

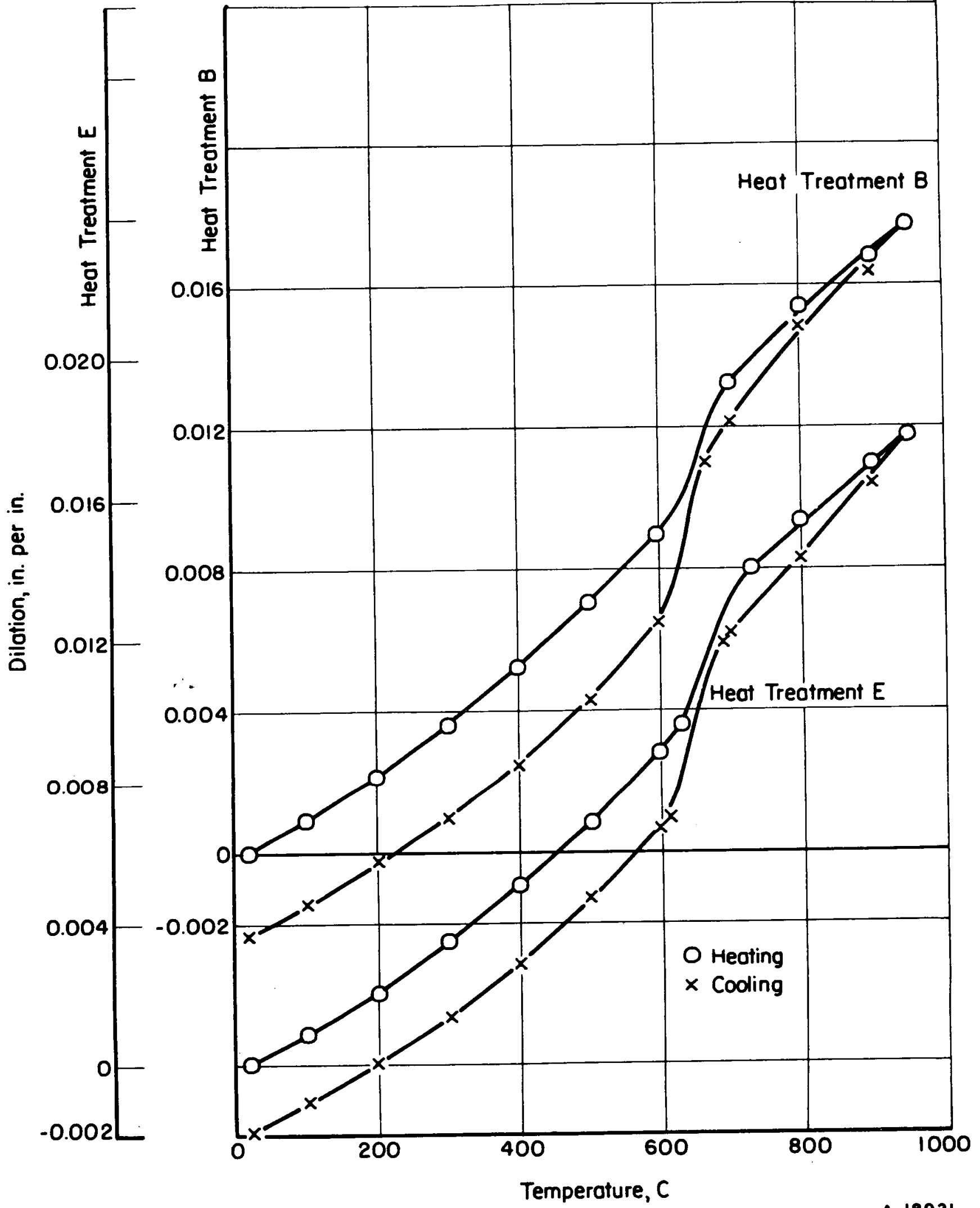

FIGURE A-10. LINEAR THERMAL EXPANSION VERSUS TEMPERATURE FOR URANIUM-15.0 w/O ZIRCONIUM 


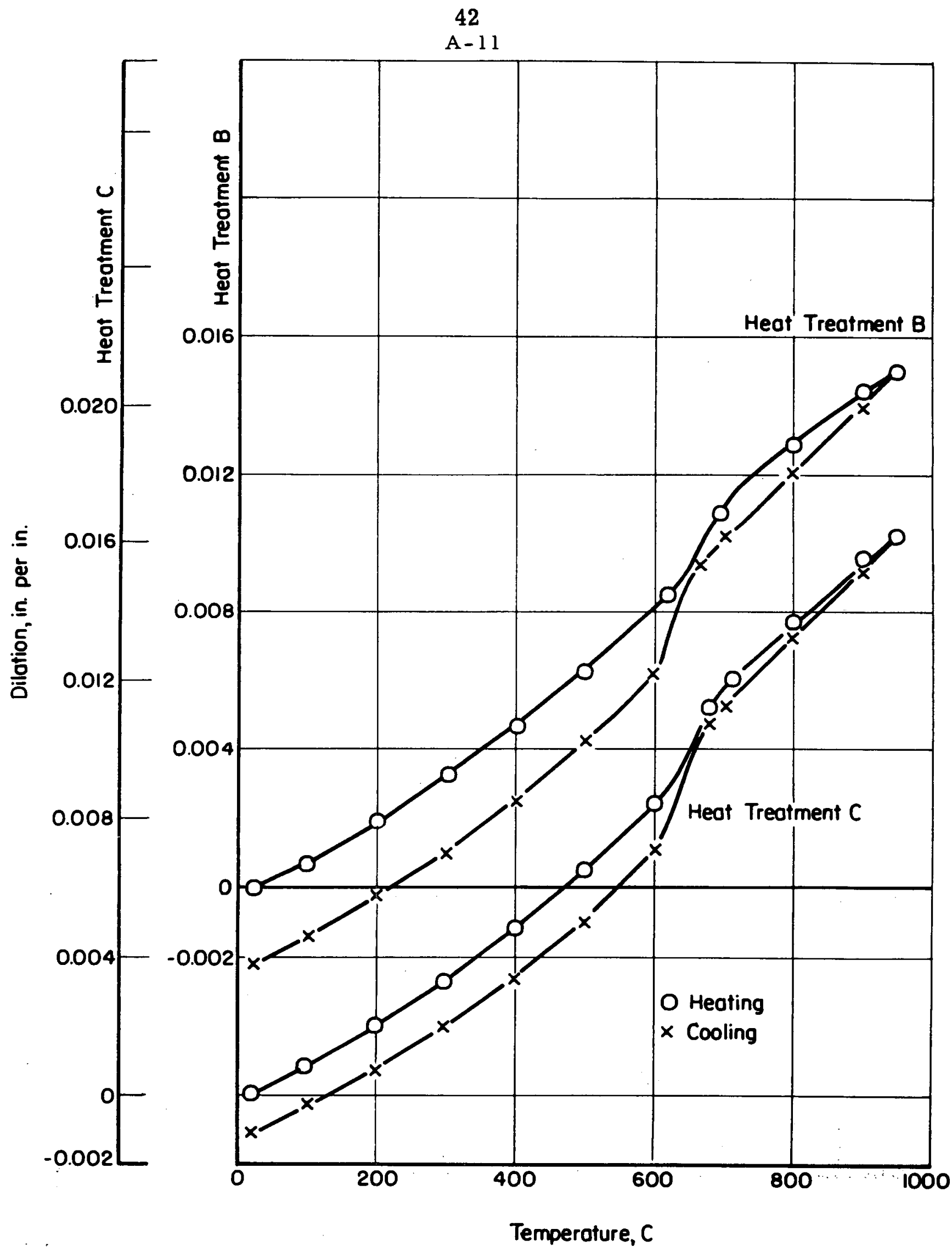

$A-18922$

FIGURE A-11. LINEAR'THERMAL EXPANSION VERSUS TEMPERATURE FOR URANIUM-20.0 w/o ZIRCONIUM 
A -12

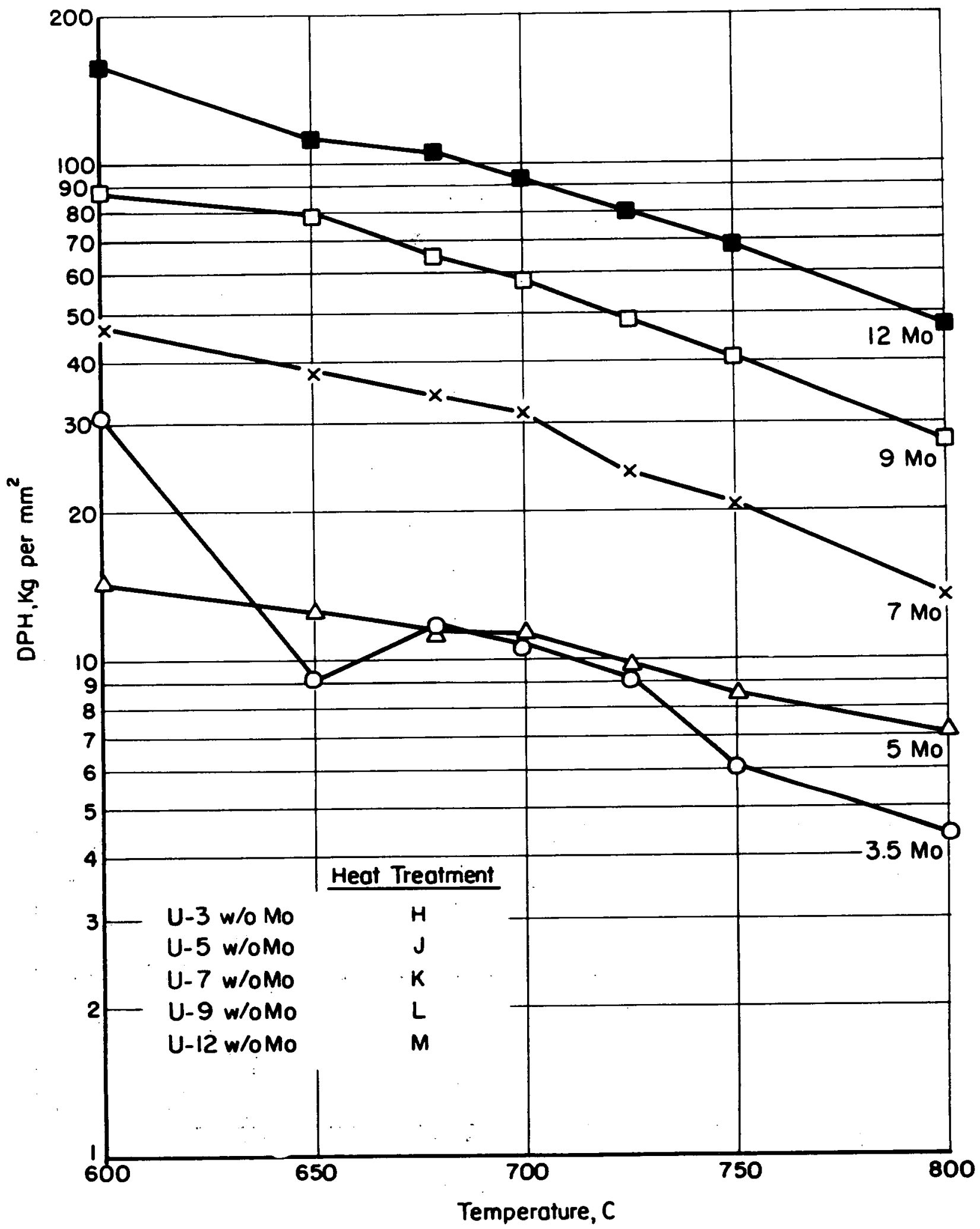

$A-18923$

FIGURE A-12. HOT HARDNESS OF URANIUMMOLYBDENUM ALLOYS 


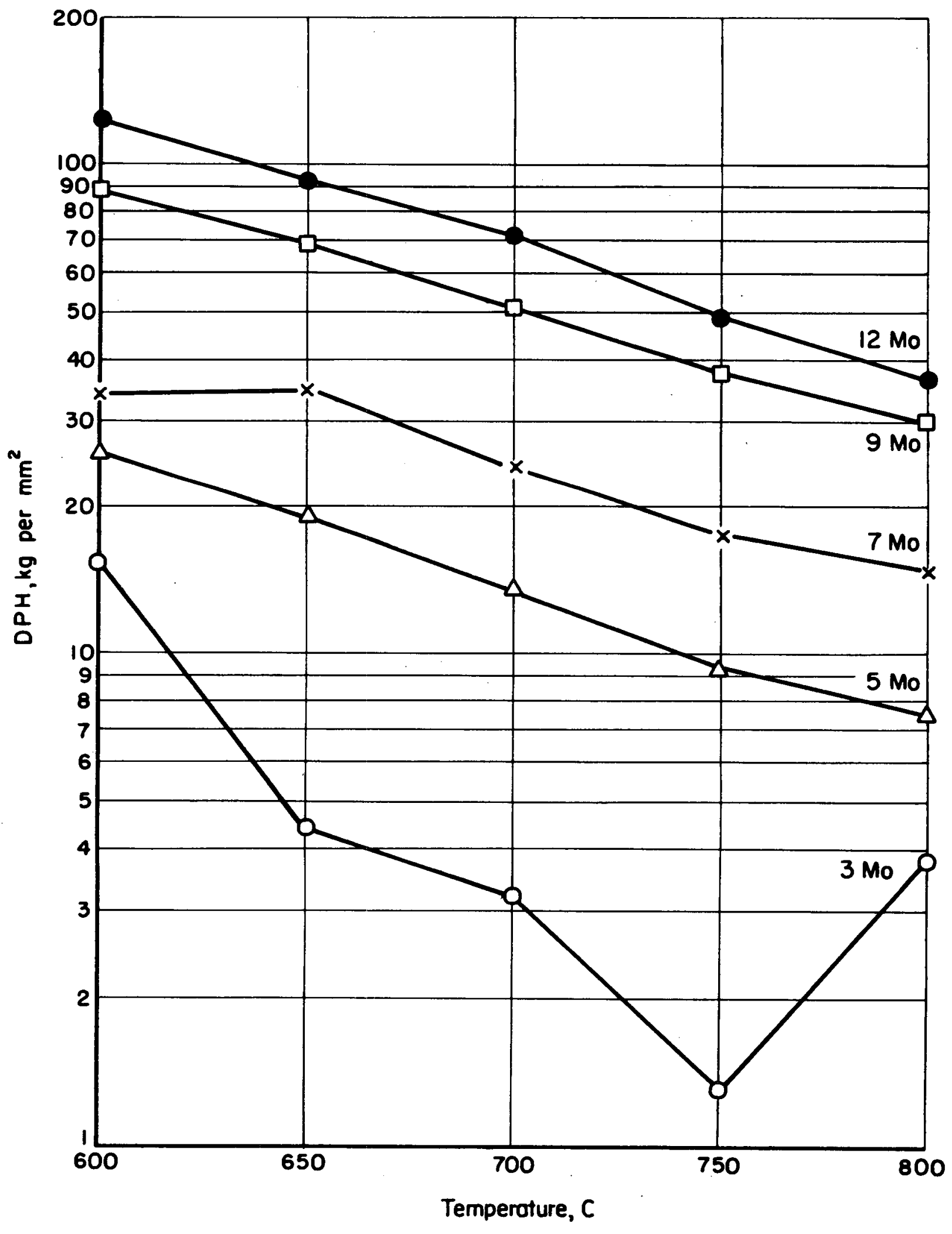

A.18924

FIGURE A-13. HOT HARDNESS OF URANIUM-MOLYBDENUM ALLOYS GIVEN HEAT TREATMENT G 


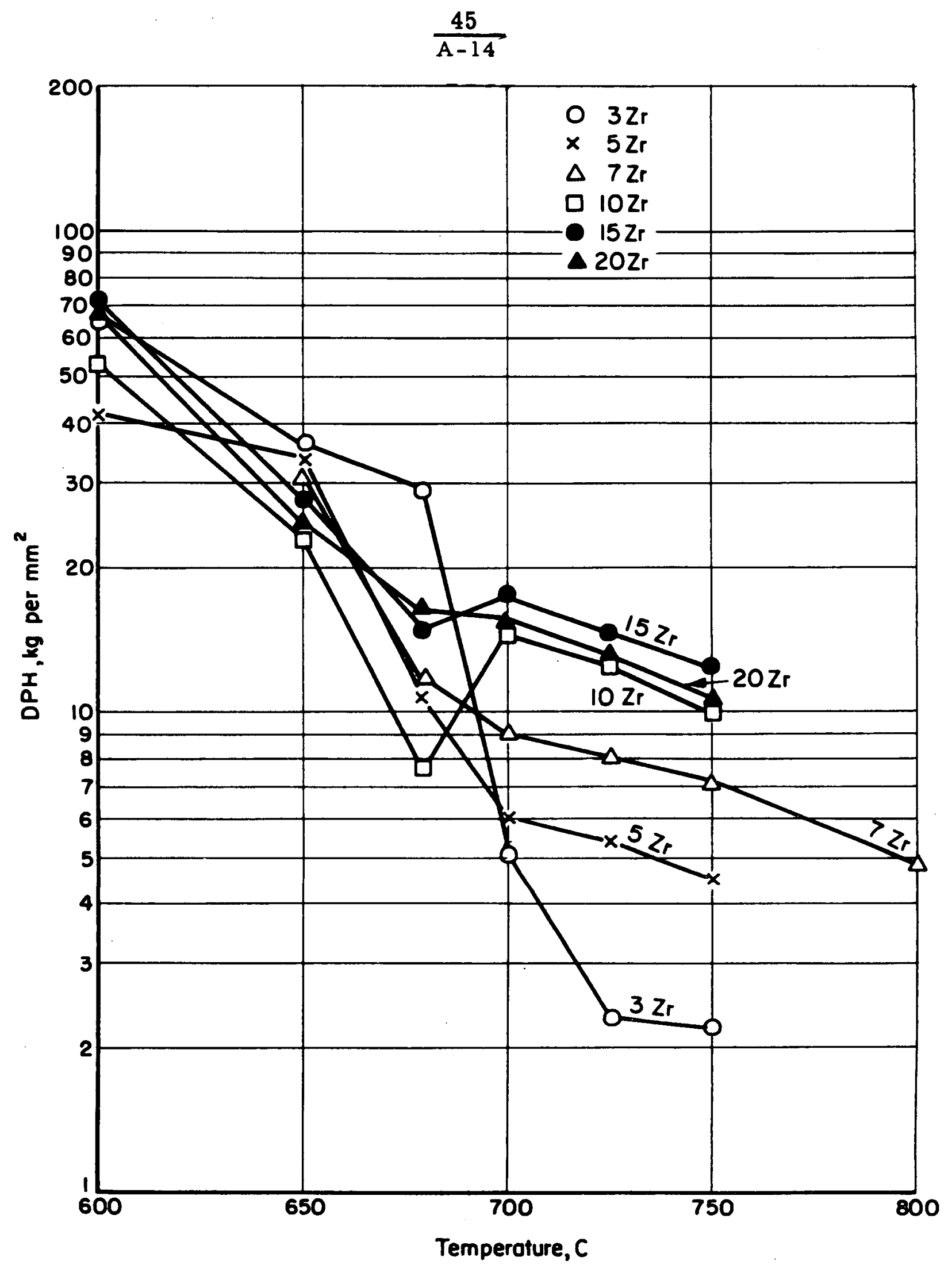

$4-18928$

FIGURE A-14. HOT HARDNESS OF URANIUM-ZIRCONIUM ALLOYS GIVEN HEAT TREATMENT A 